Original Article

\title{
Traditional knowledge about medicinal plant in the remote areas of Wari Tehsil, Dir Upper, Pakistan
}

\author{
Conhecimento tradicional sobre plantas medicinais nas áreas remotas de Wari Tehsil, \\ Dir Upper, Paquistão
}

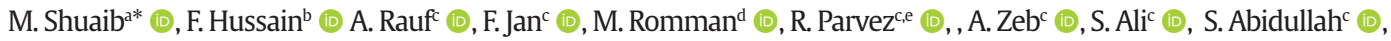 \\ S. Bahadur ${ }^{\text {(D) A. A. Shah }}$ (1) N.Azamh (1) S. Dilbari (1) K. Begumj (1) H. Khank, S. Sajjadl I. Muhammadj (1) and N.A. Shahl (1) \\ aYunnan University, School of Ecology and Environmental Science, Kunming, PR China \\ ${ }^{\mathrm{b}}$ Cholistan University of Veterinary \& Animal Sciences, Department of Microbiology, Bahawalpur, Pakistan \\ 'Abdulwali Khan University, Department of Botany, Mardan, Pakistan \\ dUniversity of Chitral, Department of Botany, Chitral, Pakistan \\ ${ }^{\mathrm{e} G o v e r n m e n t ~ G i r l s ~ D e g r e e ~ C o l l e g e ~ D a r g a i, ~ D e p a r t m e n t ~ o f ~ B o t a n y, ~ D i s t r i c t ~ M a l a k a n d, ~ P a k i s t a n ~}$ \\ fHainan University, College of Forestry, Haikou, China \\ gJazan University, Department of Medical Laboratory Technology, Jazan, Saudi Arabia \\ hUniversity of Peshawar, Centre of Plant Biodiversity, Peshawar, Pakistan \\ iUniversity of Swat, Centre of Plant Biodiversity, Swat, Pakistan \\ jUniversity of Hazara, Department of Genetic, Manshera, Pakistan \\ kUniversity of Swat, Center of Biotechnology and Microbiology, Swat, Pakistan \\ ${ }^{1}$ COMSATS University, Department of Biosciences, Park Road Islamabad, Pakistan
}

\begin{abstract}
Traditional medicine is cheaper and easily available to local people, to care for most frequent diseases in the Northern parts of Pakistan. Our study aimed at inventorying medicine from local plants, documenting their uses, and assessing their market value in 2015-2018 during spring, summer, and winter seasons. A total of 15 trips were made, 5 in each season. Semi-structured interviews with 165 inhabitant's age range between 20-80 years were conducted, analyzed the data is analyzed using Relative frequency of citation(RFC), Use Value(UV), Fidelity Level(FL), Informants consensus factor(ICF), and Jaccard index(JI) to find the most frequent and well-known used species in the area. A total of 86 species belonging to 39 vascular plant families, 33 genera were documented as medicinally important. Family Asteraceae was observed as the dominant family among all the families with 10 species, the leaf was the most used parts and decoction 36\% was the most preferred preparation type. Herb was the predominant life form (67\%). The maximum UV (0.92) was demonstrated by J. adhatoda L. species, while $A$. sativum L. shows maximum RFC (0.58), the highest ICF value represented by diarrhea and dermatitis 0.92 , and high FL value is recorded $100 \%$. According to our collections, wild species were $45 \%$, invasive species were $38 \%$ and cultivated $17 \%$ recorded, dicots species were recorded more $81 \%$. Seven 7 medicinal species is being economically important and export to the local and international market of the world, whereas P. integrima L. species were the most exported species according to the local dealers. The investigated area is rural and the local people depend on the area's plants for their health needs, and other uses like a vegetable, fuelwood, fodder, etc. The current result of RFC, UV, ICF, FL, and JI shows that medicinal flora needs to be pharmacologically and phytochemically investigated to prove their efficacy. The documentation of medicinal knowledge is important to preserve this precious old knowledge before it is lost forever, due to technological and environmental changes in the world.
\end{abstract}

Keywords: medicinal plants, economic values, quantitative study, Tehsil Wari, Pakistan.

\section{Resumo}

A medicina tradicional é mais barata e facilmente disponível à população local para cuidar das doenças mais frequentes nas áreas do norte do Paquistão. Nosso estudo teve como objetivo inventariar medicamentos de plantas locais, documentar seus usos e avaliar seu valor de mercado em 2015-2018 durante as temporadas de primavera, verão e inverno. Foram feitas 15 viagens, 5 em cada temporada. Foram realizadas entrevistas semiestruturadas com 165 moradores na faixa etária de 20 a 80 anos, com dados analisados por meio de frequência relativa de citação (RFC), valor de uso (UV), nível de fidelidade (FL), fator de consenso de informantes (CIF), e o índice de Jaccard (JI) para encontrar as espécies utilizadas mais frequentes e conhecidas na área. Um total de 86 espécies pertencentes a 39 famílias de plantas vasculares, 33 gêneros foram documentados como medicamente importantes. A família

*e-mail: zeyadz44@yahoo.com

Received: December 19, 2020 - Accepted: January 20, 2021

This is an Open Access article distributed under the terms of the Creative Commons Attribution License, which permits unrestricted use, distribution, and reproduction in any medium, provided the original work is properly cited. 


\begin{abstract}
Asteraceae foi observada como a família dominante entre todas as famílias com 10 espécies, a folha foi a parte mais utilizada e a decocção $36 \%$ foi o tipo de preparação mais preferido. A erva foi a forma de vida predominante (67\%). O UV máximo $(0,92)$ foi demonstrado pelas espécies de J. adhatoda L., enquanto A. sativum L. mostra RFC máximo $(0,58)$, o maior valor de ICF representado por diarreia e dermatite 0,92 , e alto valor de FL é registrado $100 \%$. De acordo com nossas coleções, as espécies selvagens foram $45 \%$, as espécies invasoras $38 \%$ e as cultivadas $17 \%$ registradas, as espécies dicotiledôneas foram registradas mais $81 \%$. Sete espécies medicinais estão sendo economicamente importantes e exportadas para o mercado local e internacional do mundo, enquanto as espécies de $P$. integrima $L$. foram as espécies mais exportadas de acordo com os comerciantes locais. A área investigada é rural e a população local depende das plantas da área para suas necessidades de saúde e outros usos como vegetal, lenha, forragem etc. O resultado atual de RFC, UV, ICF, FL e JI mostra que a flora medicinal precisa ser investigada farmacológica e fitoquimicamente para comprovar sua eficácia. A documentação do conhecimento medicinal é importante para preservar esse precioso conhecimento antigo antes que se perca para sempre, devido às mudanças tecnológicas e ambientais do mundo.
\end{abstract}

Palavras-chave: plantas medicinais, valores econômicos, estudo quantitativo, Tehsil Wari, Paquistão.

\section{Introduction}

Ethnobotany is a useful relationship between human beings and vegetation within their environment and its medicinal uses. Ethnobotany is the study of a particular culture and region and the uses of plants for various purposes like medicine, food, shelter, and clothing, etc. (Shuaib et al., 2014) uses in the ethnobotanical society. Both highlight the relationship between societies and their environments. The indigenous use of medicinal flora is very important culturally and scientifically as well (Murad et al., 2012).

Traditional medicine was used in most countries of the World for thousands of years (Seifu, 2004). According to the World Health Organization's [WHO] report, 60\% of the World's populations depend on herbal and traditional medicine, and $85 \%$ of the World's developing countries use traditional medicine in caring for diseases. Traditional medicine is used mostly in rural communities and underdeveloped countries. Plants are the basis for traditional medicine in developing countries all over the World. Plantbased medicine goes back 100,000 years (Razzaq et al., 2013). Throughout the World, herbal medicine has been used for the mitigation, prevention, treatment and management of various ailments since prehistoric times.

Ethnobotany of Pakistan and Khyber Pakhtunkhwa [KPK]: Pakistan occupies a unique position among all the developing countries and it has a great many different varieties of medicinal plants due to various adoption and climatic factors (Shuaib et al., 2019). Pakistan is bestowed with precious biodiversity which is categorized into nine major ecological zones. All these zones contain a lot of precious medicinal flora (Abbasi et al., 2010). It has been reported that about $12 \%$ of all the vascular plants in Pakistan are medicinally utilized (Shinwari, 2010; Ali et al., 2019b). There are also varieties of medicinal plants in the Northern and Western parts of Pakistan. Pakistan has diverse flora and about 7000 plant species are present 1, 70,000 plant species are identified. Pakistan has more than 6000 varieties of higher plants (Ali and Qaiser, 2009). Many Pakistani floras are medicinally important and are used in caring for various diseases. In early Pakistan, around 1950, 87\% of the population of Pakistan was dependent on traditional medicine (Ali et al., 2019a).

In Pakistan, traditional medicine systems are dominant in rural areas (Ahmad et al., 2003; Ali and Qaiser, 2009). There are 39,800 traditional doctors of medicine and
130,000 homeopaths registered in Pakistan. There are about 501 dispensaries and clinics providing traditional medicine to the people, 300 medicinal companies are working to make preparations of herbal medicine (Ahmad et al., 2003; Hussain et al., 2009). From the Margalla Hills, 160 medicinal plant species were found and their traditional uses and conservation were reported by (Shinwari and Khan, 2000), from the Kahuta district and Rawalpindi, 25 medicinal types of flora were found. Their traditional uses and were listed (Qureshi and Khan, 2001). A total of 124 plant uses were listed from Quetta, Chiltan National Park (Durrani et al., 2010). Seventy-two plant species were reported from Birma, South Waziristan (Farooq et al., 2012). Ninety vascular plant species, belonging to 56 families from the Hazar Nao forest of Malakand were recorded (Murad et al., 2012). Fifty-two plant species and their traditional uses from the Derro Pezo district of Lakki Marwat were noted (Zahoor et al., 2009). A large number of ethnobotanical surveys have been carried out in the Khyber Pakhtunkhwa (KPK) (Begum et al., 2005; Ibrar et al., 2007; Sher and Hussain, 2009; Shinwari et al., 2003).

The whole area of district Dir is covered by forest and is a mostly mountainous area (Shuaib et al., 2018). The research area has diverse flora and is rich in medicinal plants. The local people used these plants as remedies for various ailments. The research area has some unique biodiversity rich in species of fungi, Pteridophytes, Monocots, and Dicots, due to the presence of the Himalayas, and the Karakorum and Hindukush mountain ranges (Hamayun, 2003). Ethnobotanical studies were made in different parts of the districts, Dir Lower and Dir Upper. From Dir Lower, in Tehsil Balambat (Shuaib et al., 2014), they collected 40 medicinal plants belonging to 30 families which were used for various purposes. The same results were had in the Lower Dir Malakand valley. (Habib-Ul-Hassan et al., 2015), from the Jandool valley (Nisar and Ali, 2012), from Barawal Bandi (Hussain et al., 2014), and from the Kohistan valley (Jan et al., 2011). The current research highlights the local medicinal uses of plant in the area, medicinal values, novel uses, economic importance and transport of various medicinal plants to local and international markets, local herbal medicine, for some novel plant uses. The research area Tehsil Wari rich in plant wealth, so this study was undertaken to record the traditional knowledge and to prepare an inventory of traditional medicine for the future. 


\section{Materials and Methods}

\subsection{Study area}

The study area is called Wari and is situated in the East of District Dir upper. Wari is the name of an administrative division called tehsil which comprises villages and mountains; among the major villages are Matar, Jagam, Cheaper, Nehagdara, Proper Wari, and two mountains Skyland and Karoo. Tehsil Wari is located at 3459'52.73" N 72 $04^{\prime} 22.62^{\prime \prime} E$, with an average altitude of $975 \mathrm{~m}$ and 3200 feets Figure 1 . The study area is rural and has no education and health facilities. The district headquarters hospital (DHQ) is about 60 kilometers from the current area of tehsil Wari. The two universities are at a distance of 140 and 200 Kilometers from the local area. Dir upper has a total of 6 tehsils and our work is focused on tehsil Wari. District Dir lies in the Khyber Pakhtunkhwa province KPK, Pakistan. The village of Dir was called the headquarters of former rulers. District Dir was divided into two districts in 1996, Dir Lower and Dir Upper. Districts Dir Upper lies between 35-04 degrees and 35-46 degrees North latitude, and 71-32 to 72-22 degrees East longitude. The total area of Dir Upper is $3,699 \mathrm{Km}^{2}$ and the total population is about 760,000 . Dir Upper has boundaries on its East side with District Swat, Northside, District Chitral, on the Southside, District Dir Lower, and the Westside, Bajaur Agency. Dir Upper has two main subdivisions called Dir and Wari. This variable and unique habitat have diverse geological climatic and ecological conditions, with its traditions and culture. Geographical features of the reported area resulted in its constant dependence on natural resources and indigenous knowledge to fulfill the needs of its people. The current study aims to documents the diverse indigenous knowledge on the medicinal flora of the previously unexplored area of tehsil Wari upper Dir viz, Matar, Jagam, Cheapar, Nehagdara, Proper Wari, and two mountains Skyland and Karoo.

\subsection{Socioeconomic background of participants}

The inhabitants of the study area are Pathans and speaking Pushto language, and belong to Yousafzai tribes, who come as invaders from Afghanistan in the sixteenth century (Barth, 1981). The inhabitants in plain zones are genuinely educated and the youthful era in specific is outfitting in such manner. The plain zones are similarly more created furnished with better education and hospitals. In the mountains, areas are true without essential facilities like hospitals, education, and transport. By and large, the general populations of the study area are for the most part ranchers and dependent on wild plants as vegetables, fruits significantly as a drug. The most imperative products of the territory are wheat, maize, rice, onion, and some other vegetables. Among the vegetable spinach, mustard, turnip, radish, okra, and gourds are imperative. Peach, plum and persimmon are imperative business products of the range. Occupants of the zone

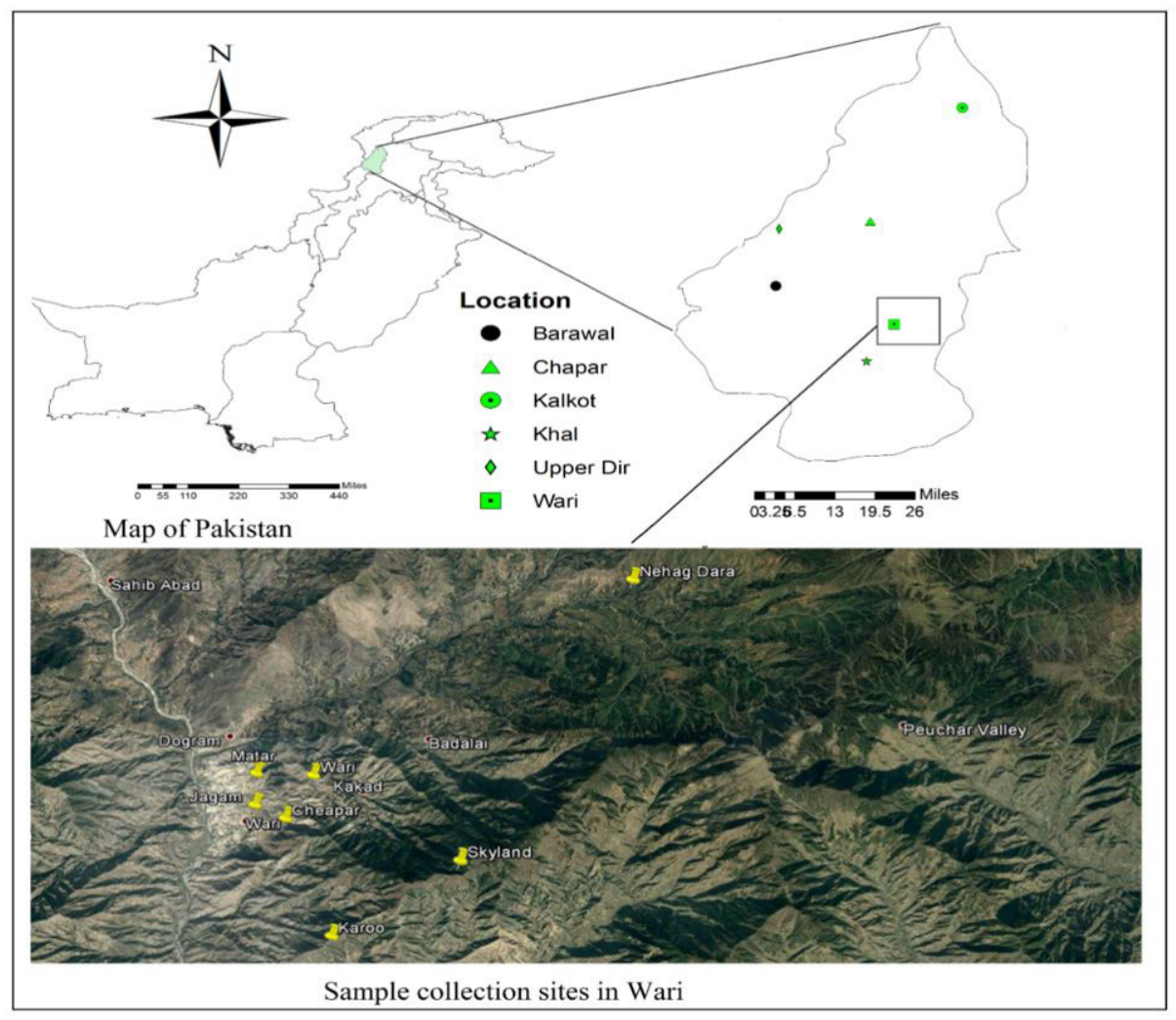

Figure 1. Map of the study area tehsil Wari, and details mentions all the collection areas. 
use wild organic products, for example, types of Pyrus, Rubus, Ficus, and Ziziphus and so forth for neighborhood and business utilize. Additionally, types of numerous genera, for example, Medicago, Chenopodium, Amaranthus, Nasturtium, Dryopteris, Rumex, Stellaria, and Malva are to a great extent utilized as wild vegetables and sent out to the nearby market.

\subsection{Data collection and identification}

Tehsil Wari is repeatedly visited in 2015-2018, for the collection of plant specimens, the collections of medicinal, ethnobotanical, conservation and plant biodiversity data. The research projects were completed in two phases, a) Field and hill trips for plant collection and $b$ ) documentation of the data obtained on the trips. During the trips to the fields and hills, random visits were completed to observe the flora, interviews of native people were also conducted with proper questionnaires, and plant biodiversity was observed in Wari, Dir Upper. Muhammad Shuaib author of paper belongs to the local area doing the fields and mountains trips and collected the species. Dr. Fida Hussain (Taxonomist) and Dr. Ikramullah Khan identifies the species. The plant nomenclature is updated using the world checklist of the selected families (Kew Science WCSP, 2021) in the present paper follows the flora of Pakistan (Tropics, 2021). The online database "The Plant List" were used for the validation of accepted and updated Latin names of species and their families (The Plant List, 2013). To understand the plant diversity within the Wari, all the available species i.e. fungi, pteridophytes, gymnosperms, and angiosperms, were collected throughout the field survey. The collected flora was pressed and mounted, while fungi and pteridophytes were preserved in bottles, after thorough washing and cleaning. All the species were identified with the available literature (Ali and Qaiser, 1993; Nasir and Ali, 1971; Stewart, 1967).

\subsection{Observation and documentation of the research data}

Extensive field trips were made to get insight into the practices of the local community, regarding the uses of local flora. During the field surveys, we observed much about the local flora, plant diversity, conservation, mode of collection, drying techniques, methods of preservation, mode of administration, harvesting times, parts used, medicinal uses, ethnobotanical uses, and how plants were processed. The local men, women, herbalists, marketers, and others who were familiar with the local flora were interviewed during the fieldwork; the data is shown in (Table 1 ). The participatory and qualitative data were collected through questionnaires, regarding the plant uses and their manner of consumption. The information collected on each plant included botanical name, local name, family, partly used, habit, species habitat, harvesting season, mode of utilization and medicinal uses. Thus the knowledge of the native people regarding their plant assets, the plant uses, religious and cultural aspects, and the conservation status of the flora was documented.
Table 1. Demographic analysis of the participants investigated.

\begin{tabular}{|c|c|c|c|c|}
\hline S. No & Variable & Categories & $\begin{array}{l}\text { No. of } \\
\text { persons }\end{array}$ & $\begin{array}{c}\text { Percentage } \\
\text { (\%) }\end{array}$ \\
\hline \multirow[t]{2}{*}{1} & Experience & $\begin{array}{l}\text { Indigenous } \\
\text { people }\end{array}$ & 161 & 97 \\
\hline & & $\begin{array}{l}\text { Traditional } \\
\text { health } \\
\text { Practitioner } \\
\text { (Herbalists) }\end{array}$ & 4 & 3 \\
\hline \multirow[t]{2}{*}{2} & Gender & Male & 115 & 70 \\
\hline & & Female & 60 & 30 \\
\hline \multirow[t]{6}{*}{3} & Age & Less than 20 & 10 & 6 \\
\hline & & $20-30$ & 38 & 23 \\
\hline & & $30-40$ & 50 & 30 \\
\hline & & $40-50$ & 35 & 21 \\
\hline & & $50-60$ & 22 & 13 \\
\hline & & $60-75$ & 10 & 6 \\
\hline \multirow[t]{3}{*}{4} & Religion & Muslims & 165 & 100 \\
\hline & & Hindu & 0 & 0 \\
\hline & & Christian & 0 & 0 \\
\hline \multirow[t]{7}{*}{5} & Education & Illiterate & 60 & 36 \\
\hline & & Primary & 28 & 17 \\
\hline & & Middle & 20 & 12 \\
\hline & & $\begin{array}{c}\text { Secondary } \\
\text { passed }\end{array}$ & 27 & 16 \\
\hline & & $\begin{array}{l}\text { Higher } \\
\text { secondary }\end{array}$ & 19 & 12 \\
\hline & & Undergraduate & 09 & 06 \\
\hline & & Post graduate & 02 & 1.2 \\
\hline
\end{tabular}

\subsection{Economic value of Dir Upper Wari}

Wari Dir Upper is rich in varieties of flora and has a diverse habitat. The flora is economically very important to the local people, who use it in caring for various diseases. Herbalists make traditional medicines which are the most common way available for caring for the most frequent diseases. The regional plant dealers sell the plants to local markets and export them to the International market as a way of earning money.

\subsection{Data analysis}

\subsubsection{Relative frequency citation ( $R F C$ )}

The collected ethnobotanical data were quantitatively analyzed using the Relative Frequency Citation (RFC) index. This indicator shows the local importance of each species and is calculated from the frequency of citation (FC, the number of informants mentioning the usage of the species) divided by the total number of informants in the survey $(\mathrm{N})$, without considering the use categories (Kayani et al., 2014). 
RFC can be defined by Formula 1

$$
\mathbf{R F C}=\frac{F c}{N}
$$

The value ranges from zero (none of the informants cites the plant as useful) to one (every informant report the plant to be useful) (Sadeghi et al., 2014).

\subsubsection{Use Value (UV)}

The Use Value (UV) demonstrates the relative importance of locally known plants (Ong and Kim, 2014). It is calculated using Formula 2

$$
\mathbf{U V i}=\frac{\sum U V i}{N}
$$

Where Ui is the number of use mentioned by each informant for a given species and $\mathrm{N}$ is the total number of informants

\subsubsection{Informants consensus factor (ICF)}

ICF is used to measure the homogeneity of information among the informants regarding particular types of ailment categories in Formula 3 (Kadam and Bhalerao, 2010).

$$
\text { ICF }=\frac{n u r-n t}{n u r-1}
$$

Where "nur" denotes the number of users report for particular ailment categories. "nt" the number of taxa used for a particular use category by all informants. The ICF results range from 0 to 1 . The high value close to 1 means that taxa are used by large proportions of the informants for numbers of related broad categories, whereas the low value close to 0 means the plant species is randomly chosen for few or single conditions or the informants did not share information about the use of plants (Sharma et al., 2012).

\subsubsection{Fidelity Level (FL)}

Since many plant species may be used for some disease, so it is important to find the most frequently used species (Musa et al., 2011) which is calculated through FL formulated by (Friedman et al., 1986) in Formula 4.

$$
\text { FL }(\%)=\frac{\mathbf{I p}}{\mathbf{I u}}
$$

Where "Ip" is the number of informants who provided information's about the use of species for particular ailment categories. And " $\mathrm{I}_{\mathrm{u}}$ " the number of informants starting the use of the plant for any ailment category. High FL value (near to 100\%) obtained from the plant for which almost used report refer to the same category, whereas the low FL value obtained for the plant that is used for different disease category (Musa et al., 2011). Similarly, the high FL value confirms high usage of the plant species for a particular ailment. While low FL value confirms the wide range of medicinal uses but with a low frequency for each ailment.

\subsubsection{Jaccard index (JI)}

Ethnobotanists calculate the JI for comparison of the documented data with previously published data collected from the adjoining area (Zahoor et al., 2017). Jaccard index (JI) is calculated by using the following Formula 5.

$$
J I=\frac{\mathbf{C} \times 100}{(\mathbf{a}+\mathbf{b})-\mathbf{c}}
$$

Where "a" is the number of species of area A (Matar, Jagam, Cheapar, Nehagdara, Proper Wari, and two mountains Skyland and Karoo) and "b" is the number of species in area B, which includes Kohistan valley, Sheringal valley, Chitral, Gilgit Baltistan, Swat valley, Malakand valley, Jandool valley, Lower Dir, Kabal Swat valley, Barawal valley, Bunner valley, Abbottabad, Khyber agency, Mangowal District Gujrat Panjab, Hafizabad, Panjab and "c" the number of species common in both A and B.

\subsubsection{Data analysis}

The data about medicinal plant collect through a questionnaire from the local peoples and healers, then analyzed through FC, RFC, UV, ICF, Fl, and JI. The area map developed through GIS, and the figure developed through RAW GRAPHS (Mauri et al., 2017). Descriptive Statistics use for describing, presenting, summarizing and organizing data, either through numerical calculations or graphs or tables. RAW Graphs is an open-source data visualization framework built to make the visual representation of complex data easy for everyone. Mauri et al. (2017) Alluvial diagrams which allow representation flows and to see correlations between categorical dimensions, visually linking to the number of elements sharing the same categories. It is useful to see the evolution of a cluster (such as the number of people belonging to a specific group). It can also be used to represent bipartite graphs, using each node group as dimensions. Used a scatter plot, it is a type of mathematical diagram using Cartesian coordinates to display values for two variables for a set of data. The data is displayed as a collection of points, each having the value of one variable determining the position on the horizontal axis and the value of the other variable determining the position on the vertical axis. This kind of plot is also called a scatter chart, scattergram, scatter diagram, or scatter graph. Used Dendrograms, they are tree-like diagrams used to represent the distribution of hierarchical clustering. The different depth levels represented by each node are visualized on the horizontal axes and it is useful to visualize a non-weighted hierarchy. Used a bar chart that presents grouped data with rectangular bars with heights proportional to the values that they represent.

\section{Results and Discussion}

The current investigations are one of the very populated ranges of Tehsil Wari which stayed unexplored in the past investigations. From Tehsil Wari, this is the first comprehensive documentation of medicinal species.

\subsection{Demographic data of tehsil Wari}

The ethnobotanical research was conducted in Tehsil Wari, Dir Upper in 2013-2015 during spring, Summer, and Winter seasons. A total of 15 fields and mountain trips were made, 5 in each season. In the present study, semi-structured interviews with 165 inhabitant's age range between 20-80 years were conducted in (Table 1 ). Among the 165 informants mostly were indigenous people, having $97 \%$ were local peoples and 3\% were traditional health practitioner (herbalist), 70\% 
male and $30 \%$ female represents (Table 1 ). At the age of 30 to 40 years represents more people having $30 \%$. Due to Lack of educational facilities illiterate ratio was more in the local area having 36\%. Many informants had an education with primary education $17 \%$, middle and high secondary education were $12 \%$, secondary education passed $16 \%$, undergraduate education is $6 \%$, and postgraduate education has less ratio $1.2 \%$ (Table 1). The local community of people is Muslims $100 \%$, Hindu 0\%, and Christian 0\%. Majority of people in the local area is speaking Pushto Language. Despite the changing trends towards moderns synthetic medicine, most people like and prefer herbal medicine because to avoid the side effects of modern medicine (Gilani and Atta-ur-Rahman, 2005; Shah et al., 2016; Shinwari, 2010).

\subsection{Medicinal plant diversity}

The study area falls in the moist temperate climatic region having rich floral diversity. The area represents large numbers of medicinal species. The diversity shows 86 medicinal species out of that Dicots were recorded $81 \%$, followed by Monocots 8\%, Gymnosperms 5\%, Pteridophytes $4 \%$, and fungi $2 \%$ (Figure 2 ).

\subsection{Parts of medicinal plants for curing diseases}

In the current medicinal plants survey Whole plants were utilized most frequently for medicinal purpose $31(36 \%)$ uses were reported, followed by $25(31 \%)$ leave only uses, 14 (16\%) fruit uses, $13(15 \%)$ uses of wood, $7(8 \%)$ uses of seeds, $6(7 \%)$ flower uses, $5(6 \%)$ uses of roots and shoot each, 4 (5\%) uses of bark, $3(4 \%)$ each uses of stem and resins, 2(2\%) each uses of cones, rhizome, and capsule, while $1(1 \%)$ each uses of frond, nuts, sap, achene, and grain Figure 3 and Table 2. A large number of human ailments were treated by the native healers, like dysentery, diarrhea, hepatitis, cough, malaria, stomach ache, constipation, jaundice, cancer, fever, and seizures.

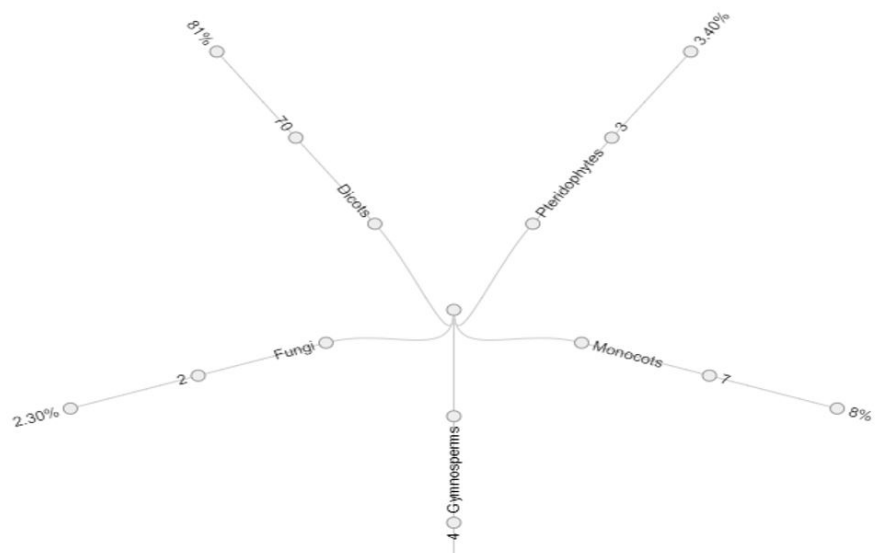

Figure 2. Total diversity of species in the local area with their percentages.

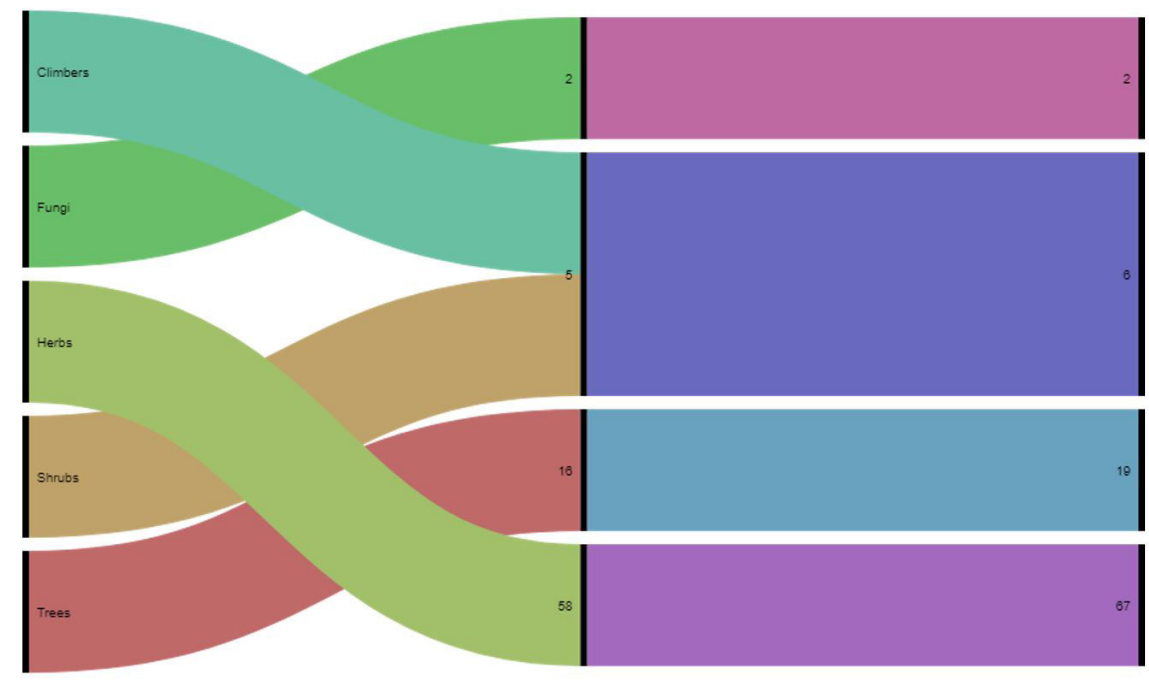

Figure 3. Life form of medicinal plants in the study area. 


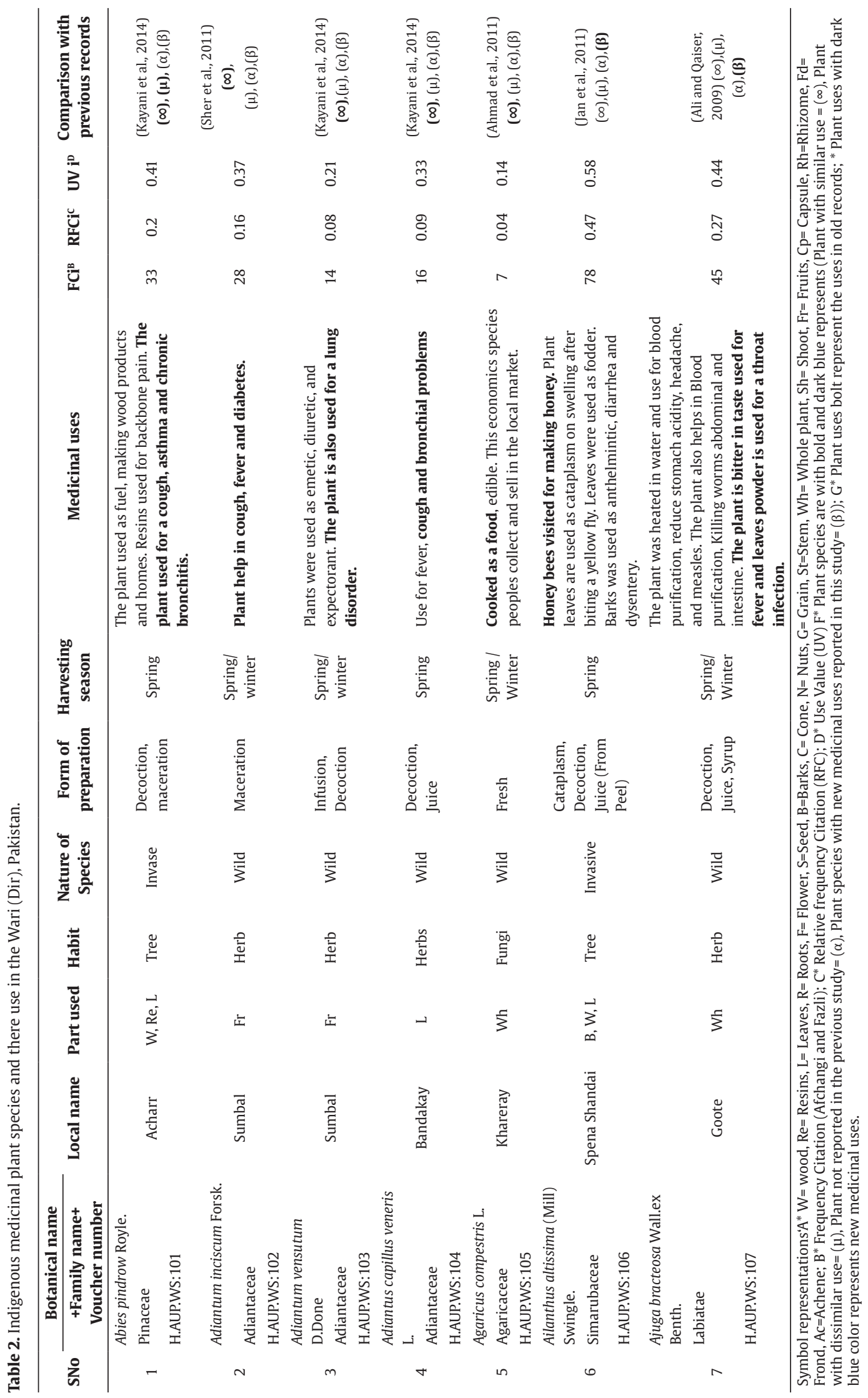




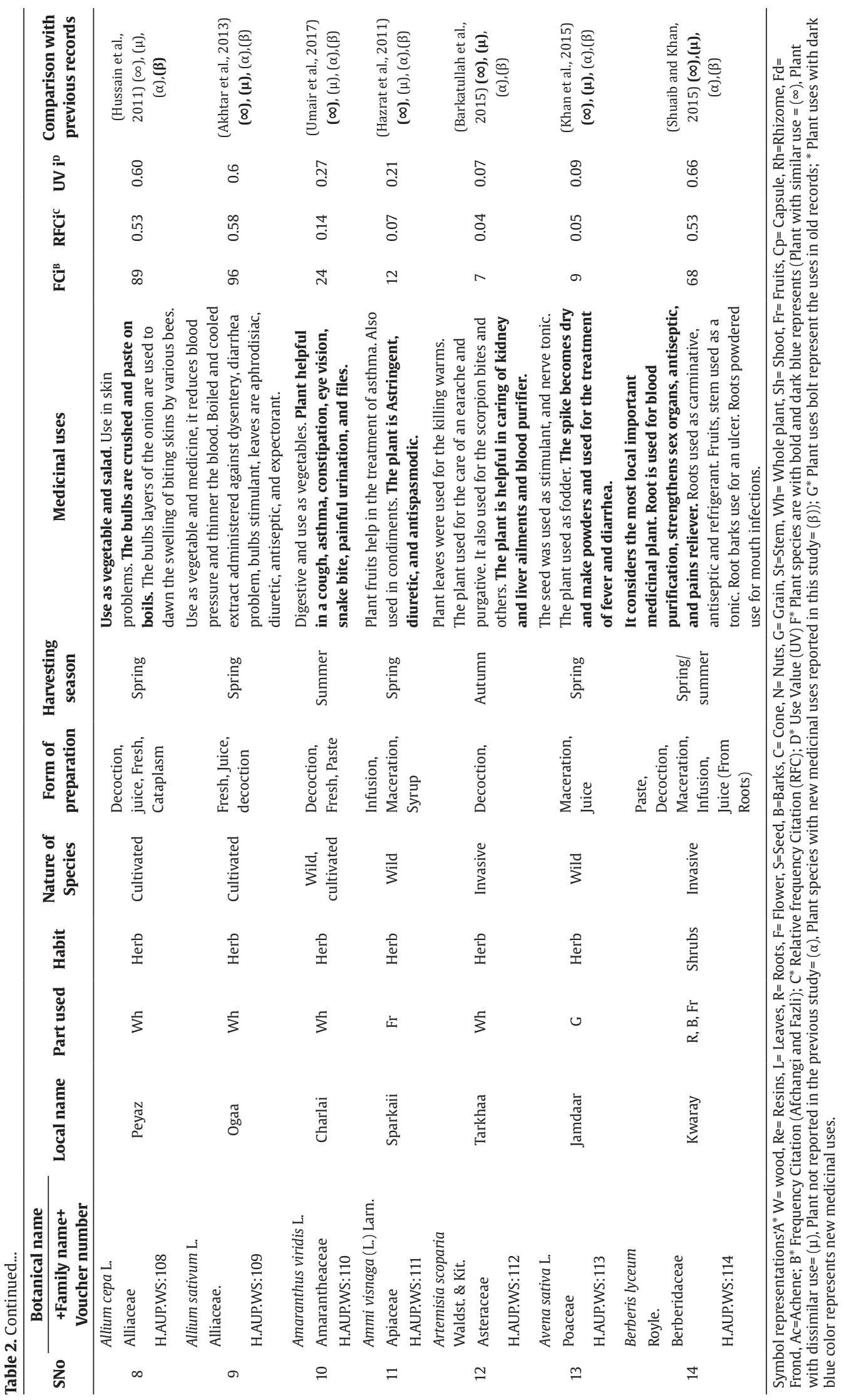




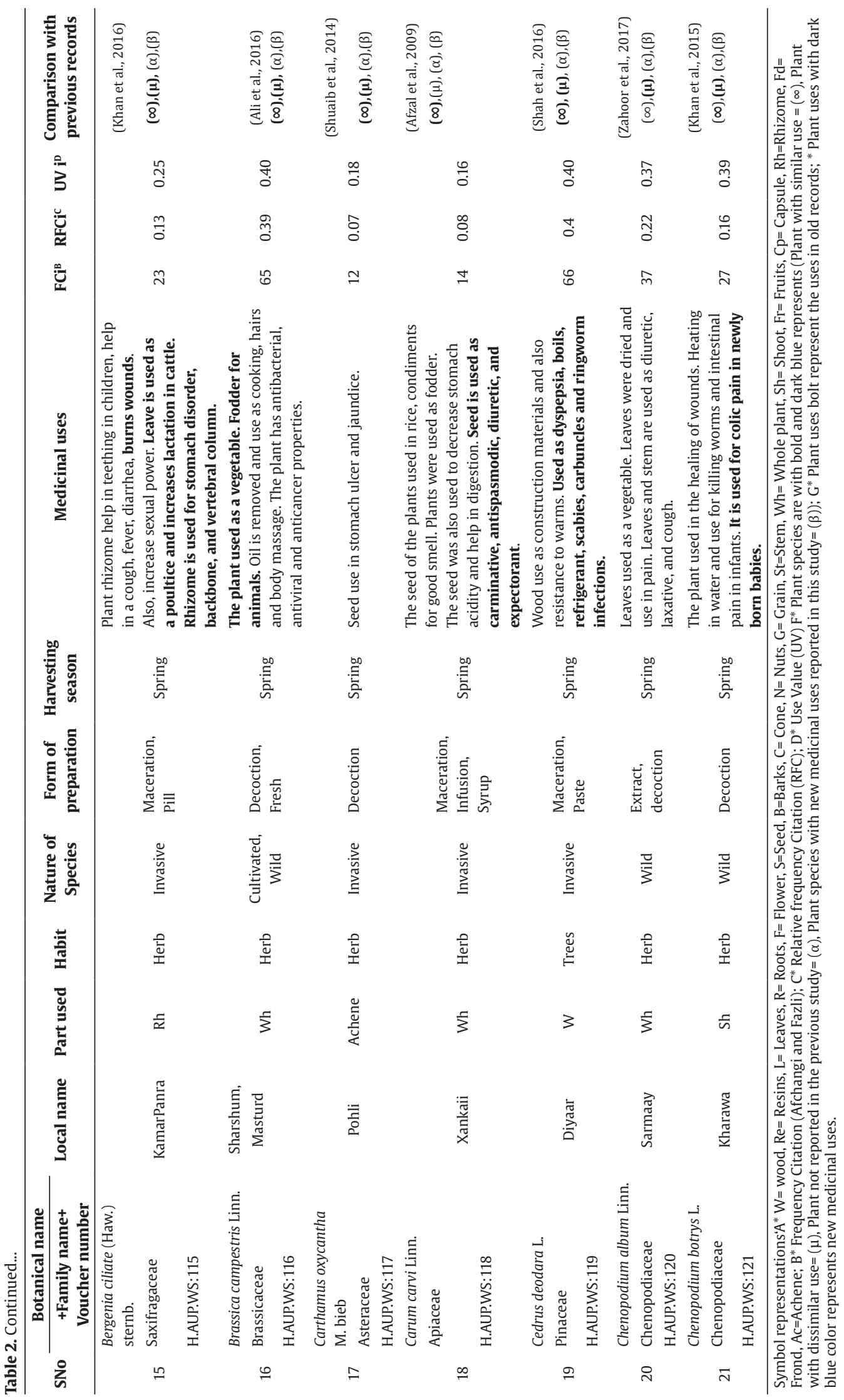




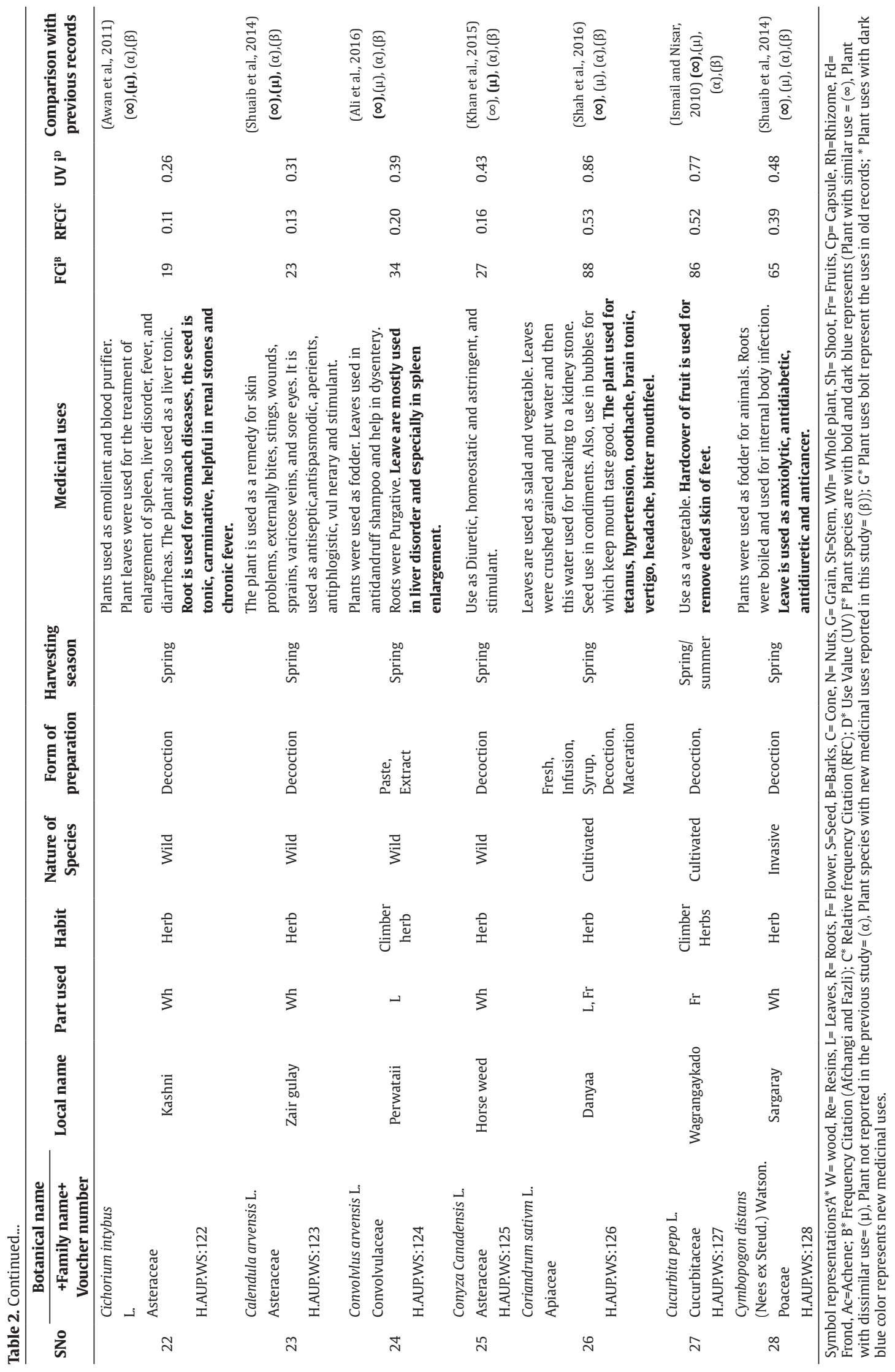




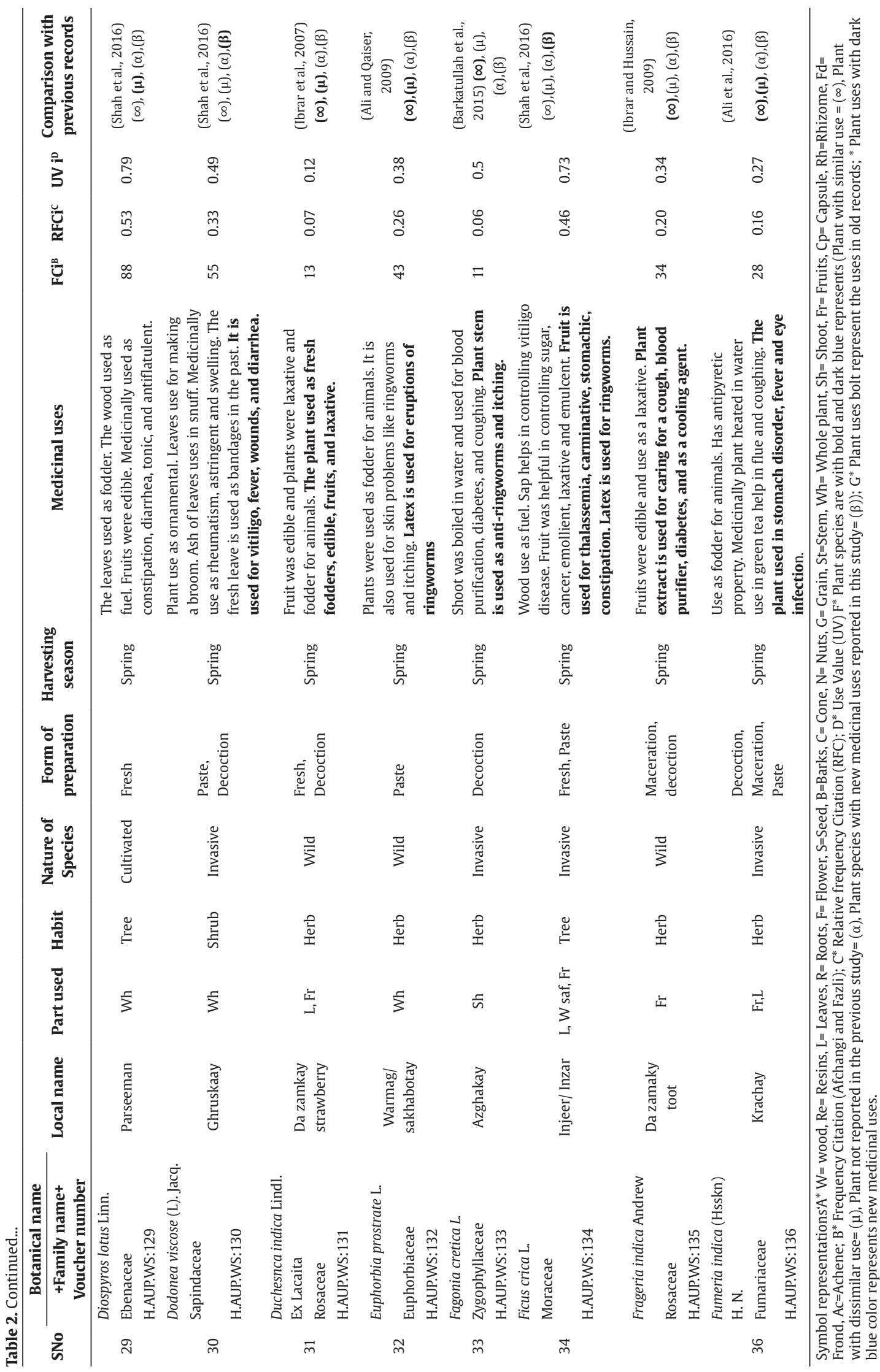




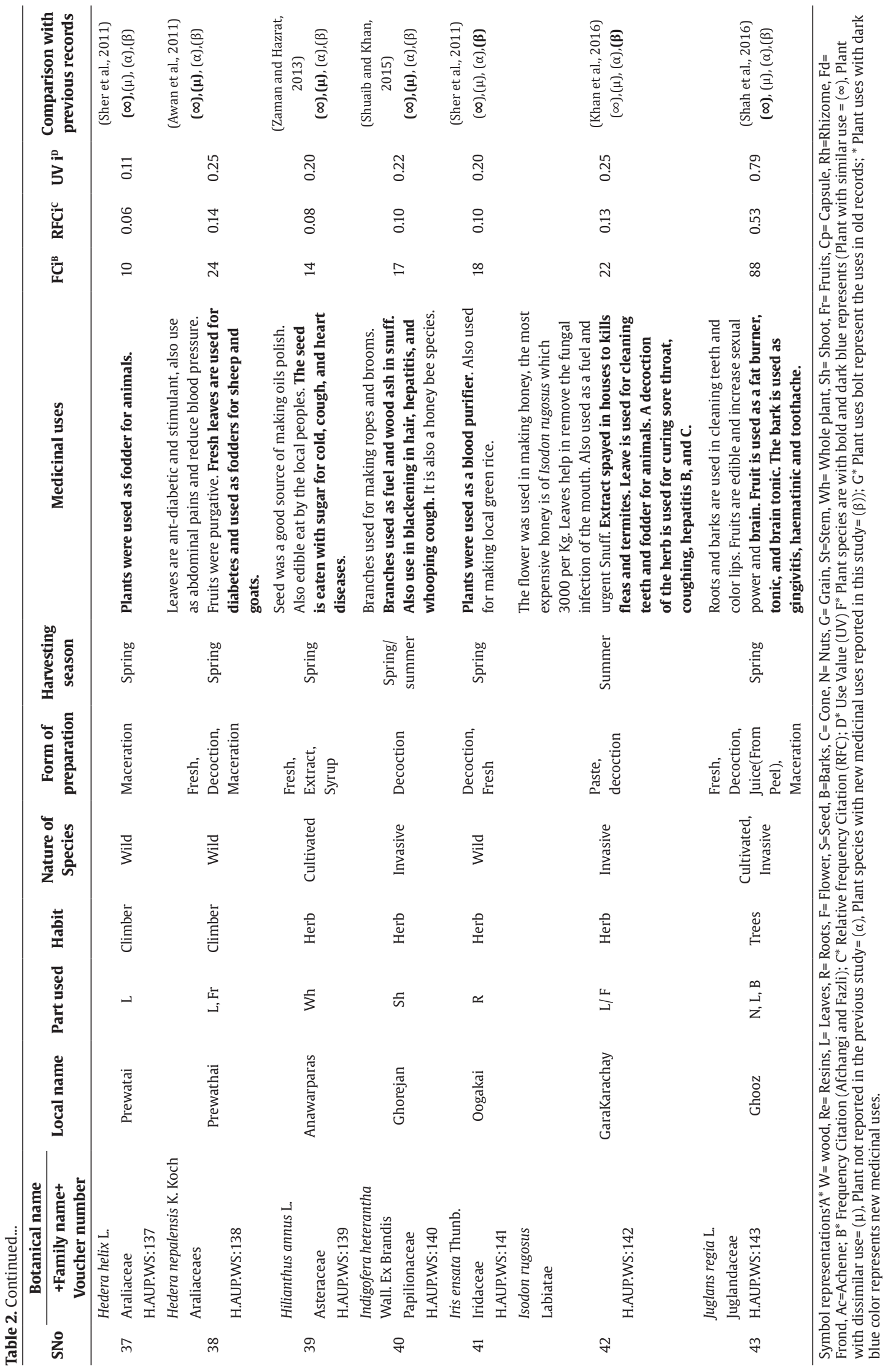




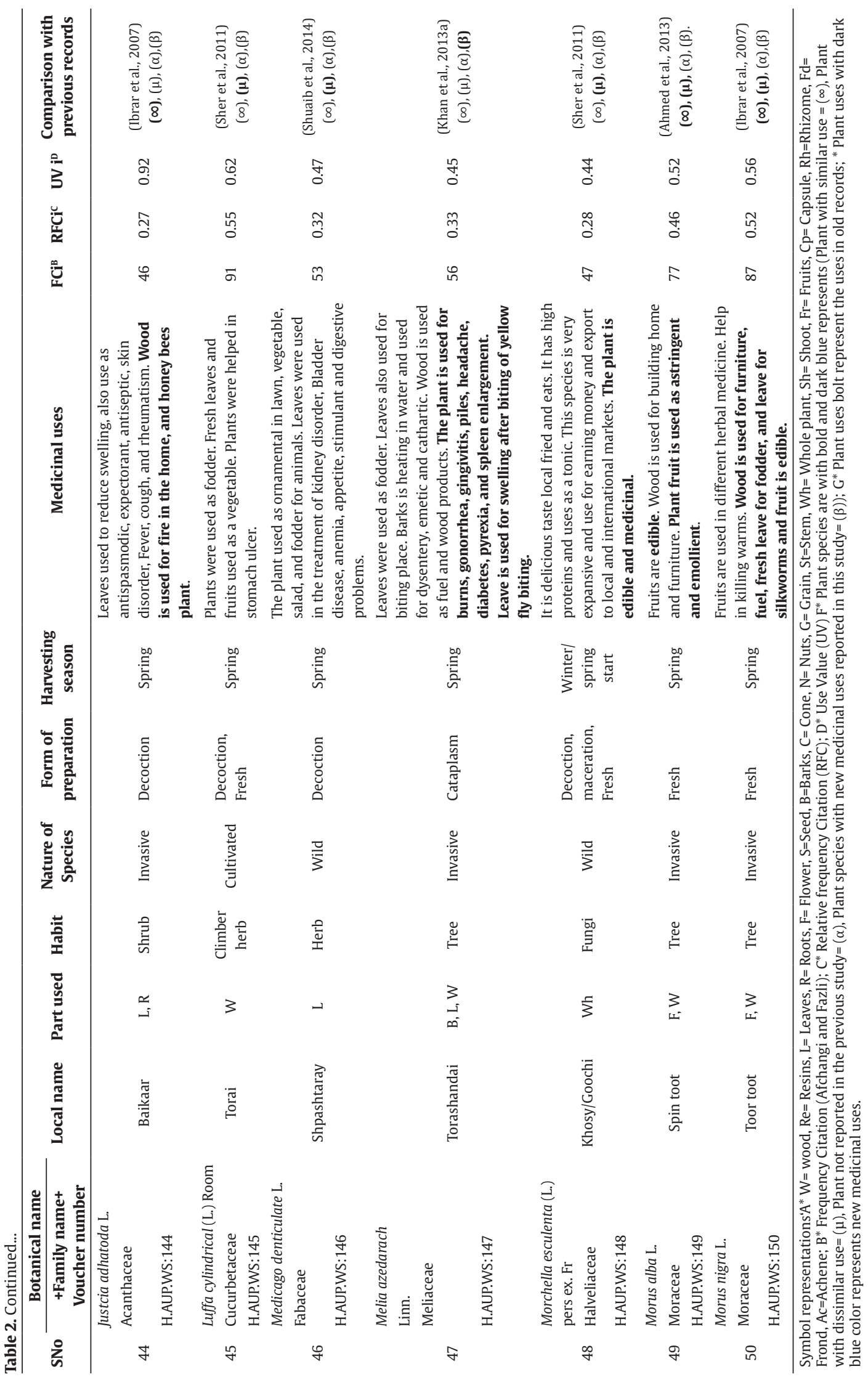




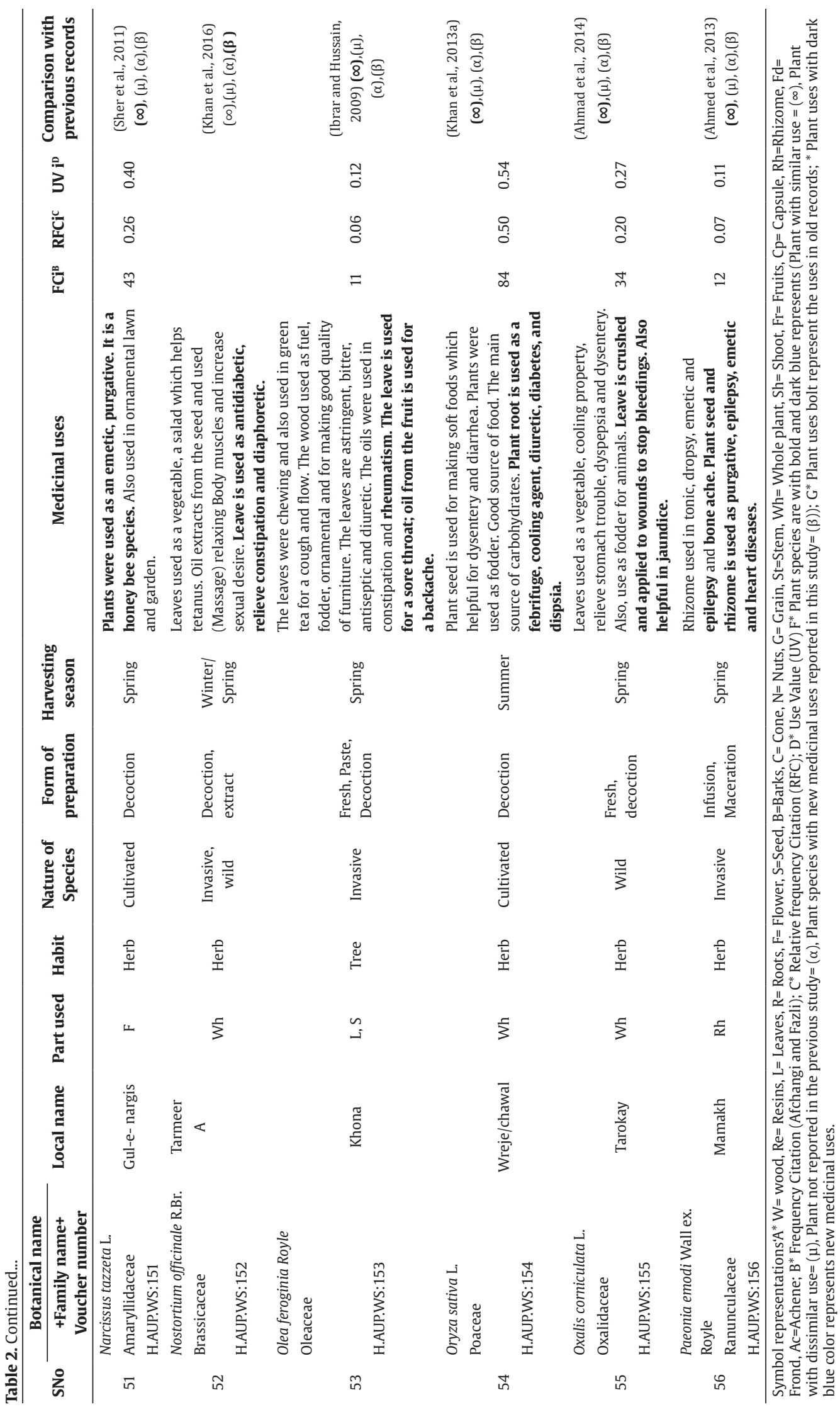




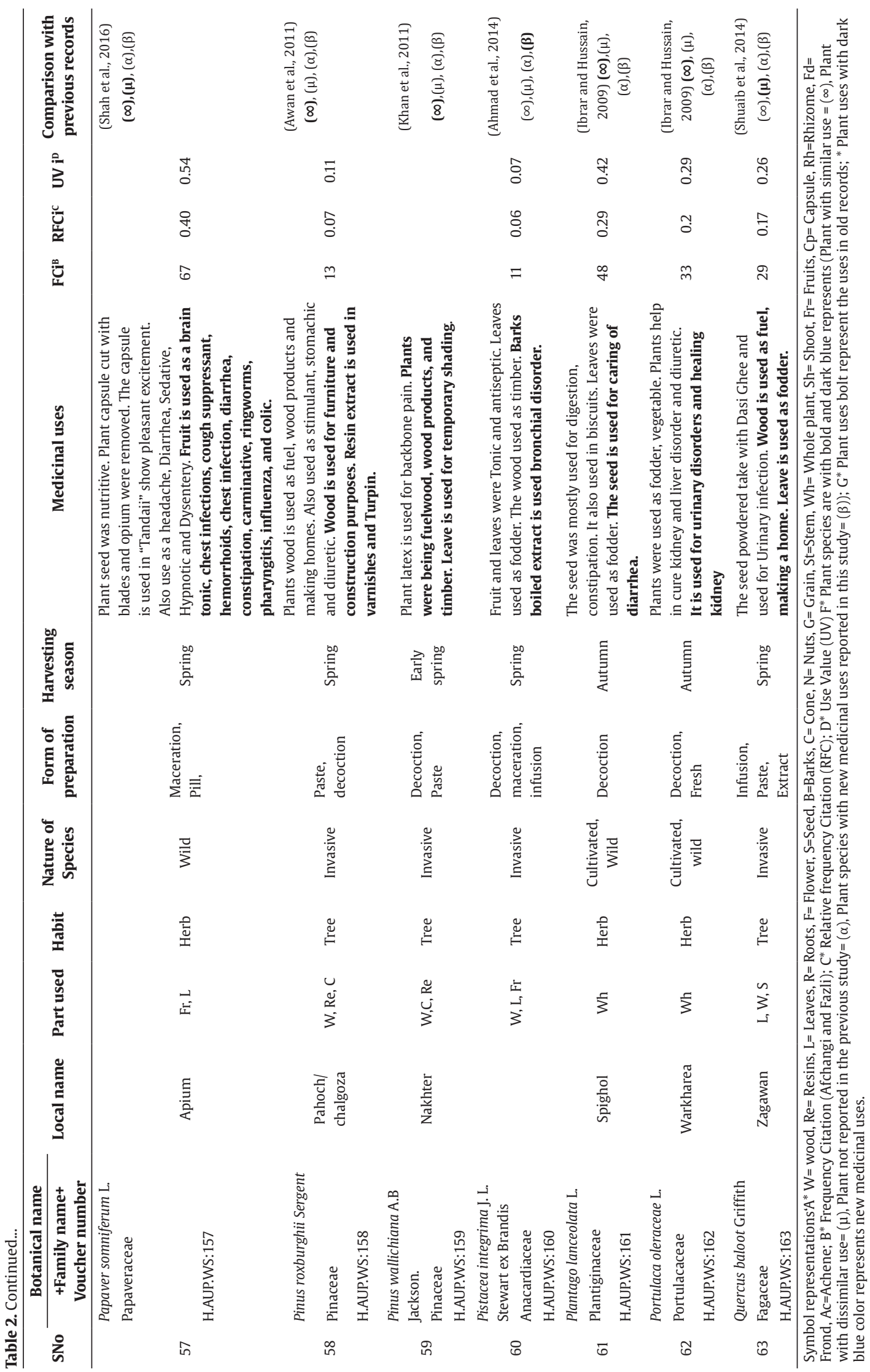




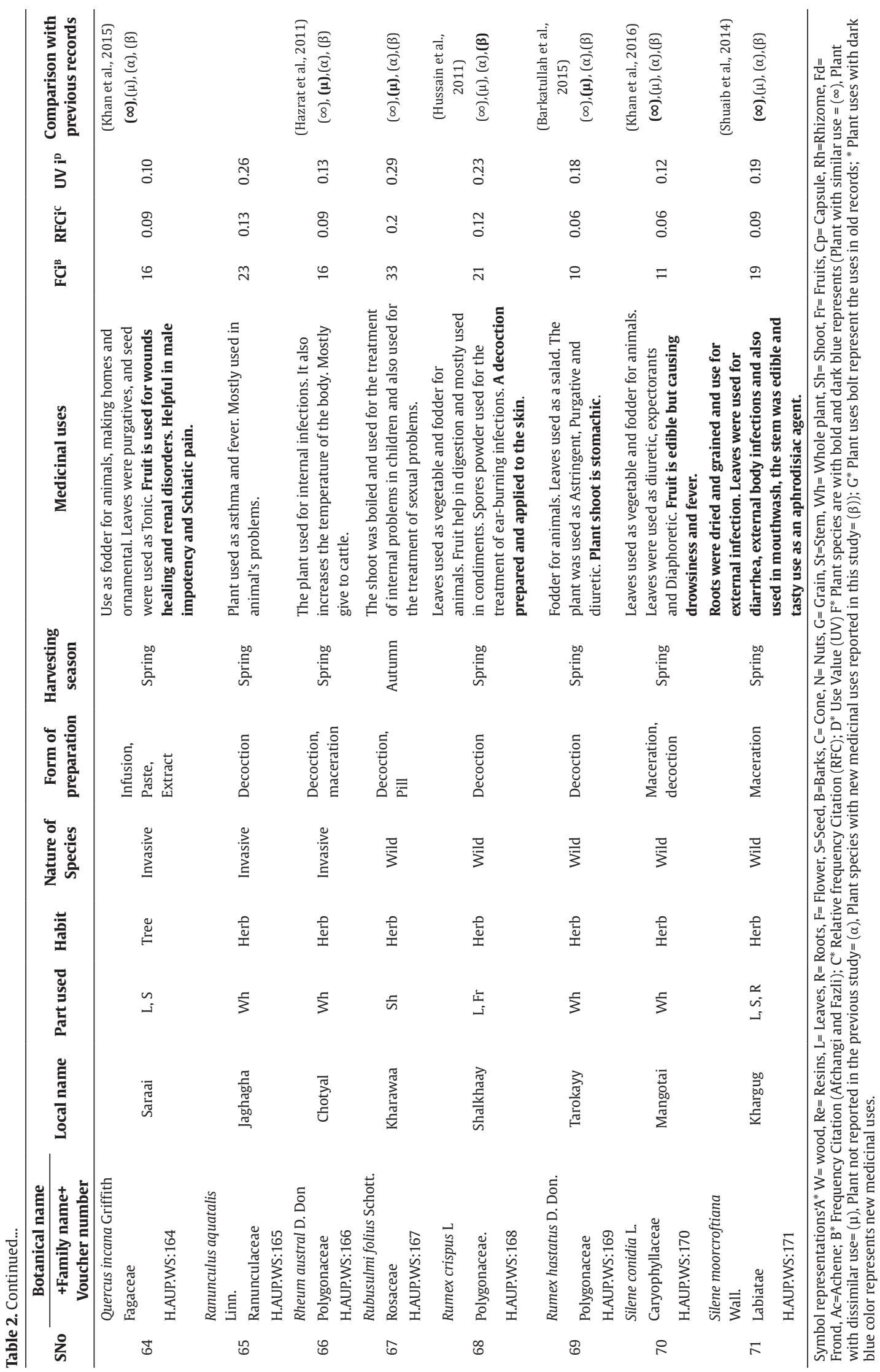




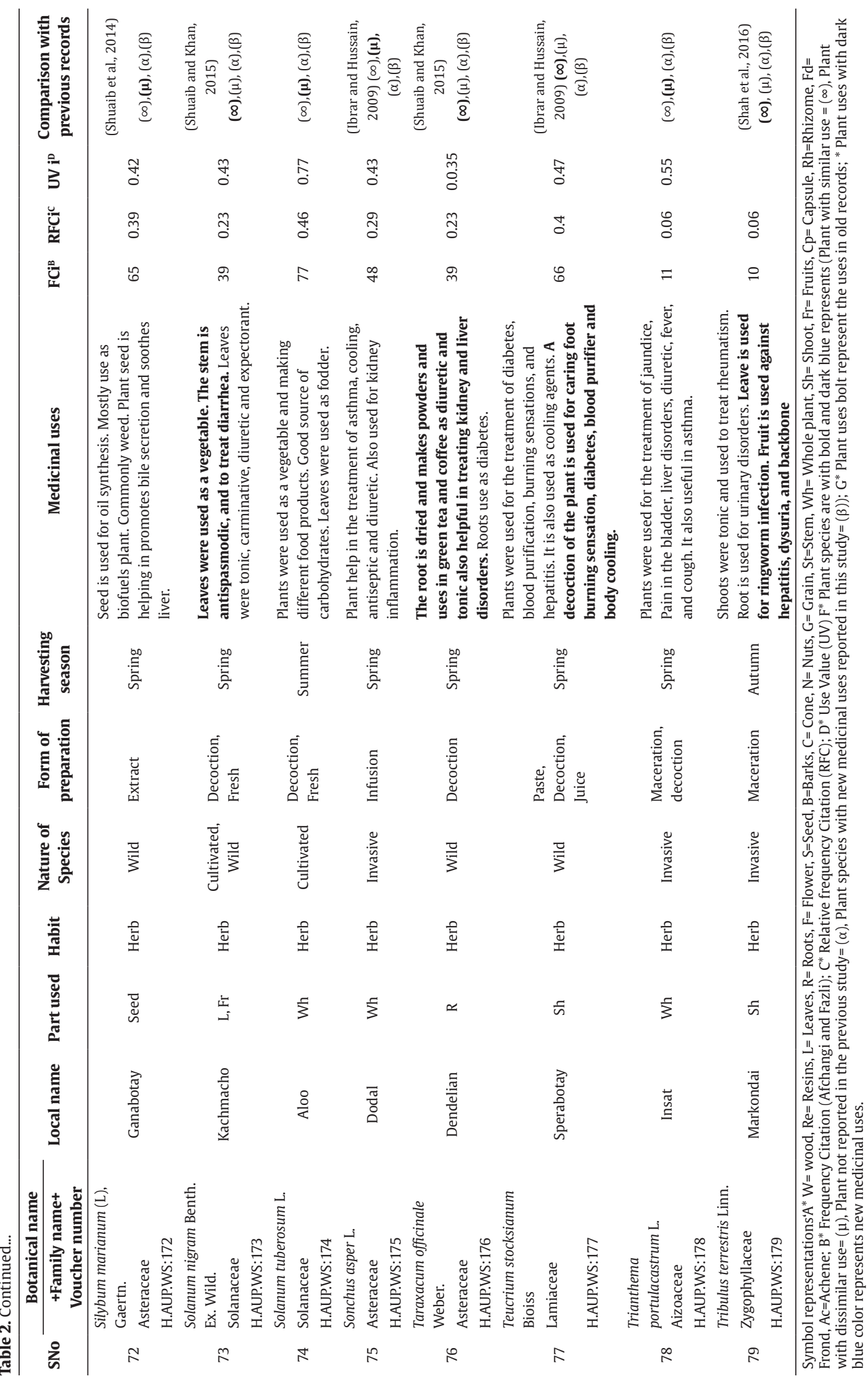




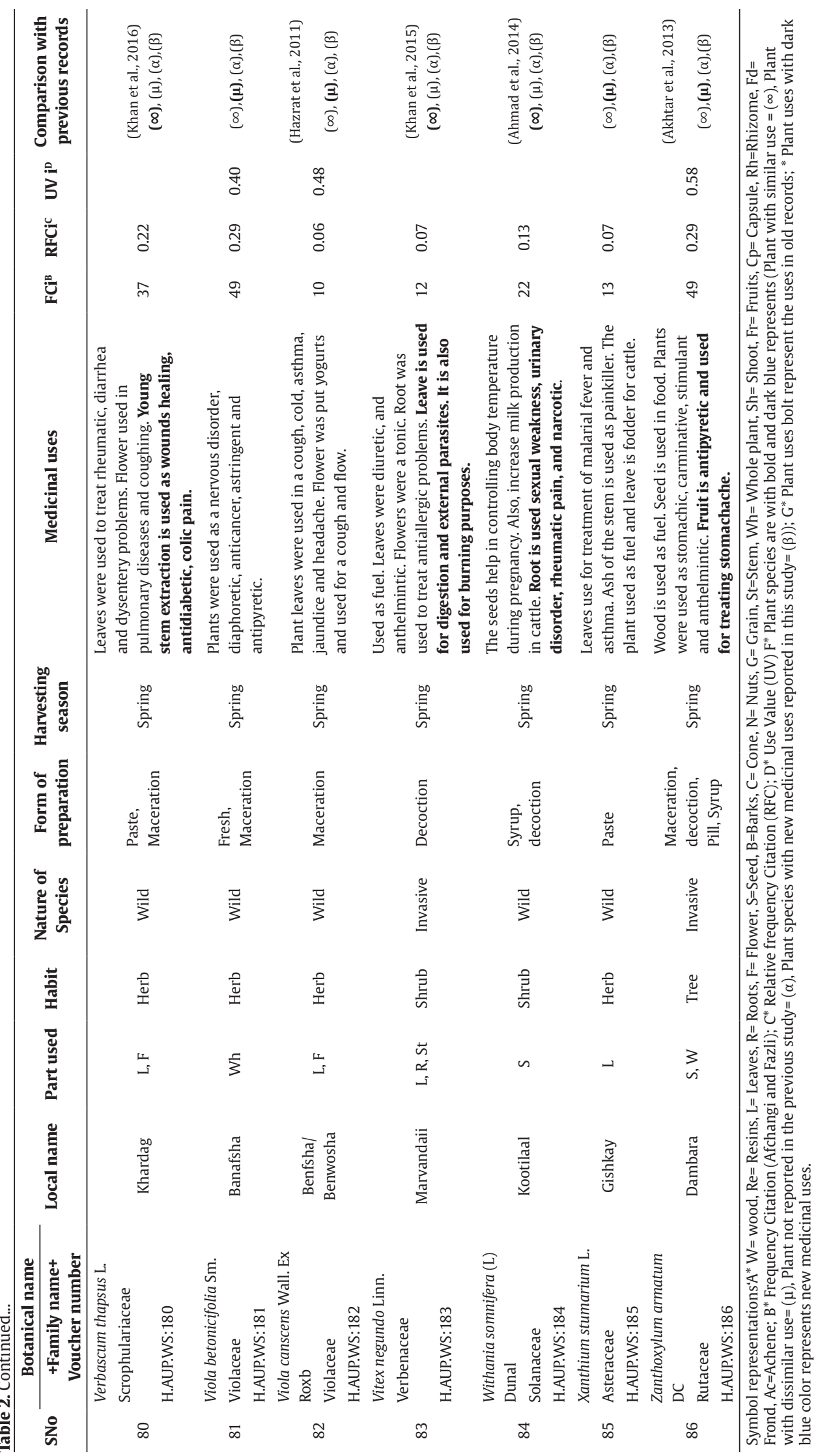




\subsection{Life form and nature of species}

During our ethnobotanical survey, a total of 86 species, belonging to 33 families, and 33 genera were collected from the survey area and explored. Informants reported that 58(67\%) herbs were used the most used, followed by $16(19 \%)$ trees, $5(6 \%)$ climbers, and 5(6\%) shrubs, while fungi represented by $2(2 \%)$ species (Figure 4 ). According to our collections, a total of 86 species includes $45 \%$ wild species, $38 \%$ invasive species, and $17 \%$ cultivated species (Figure 5, Table 2).

\subsection{Form and mode of utilization}

In this review, generally, plants were accounted for inward applications. The crude preparations of herbal medicine, medicinal plant parts were grouped into 10 categories. They were utilized either as decoction (36\%), followed by Maceration (16\%), Fresh (16\%), Paste (9\%), Juice and infusion (6\%), Extract and syrup (4\%), Pill (3\%), and Cataplasm (2\%) in Figure 6. This type of usage is basic in other parts of Pakistan especially and in the World by and large (Yineger et al., 2007). The decoction was made by heating the plant parts in

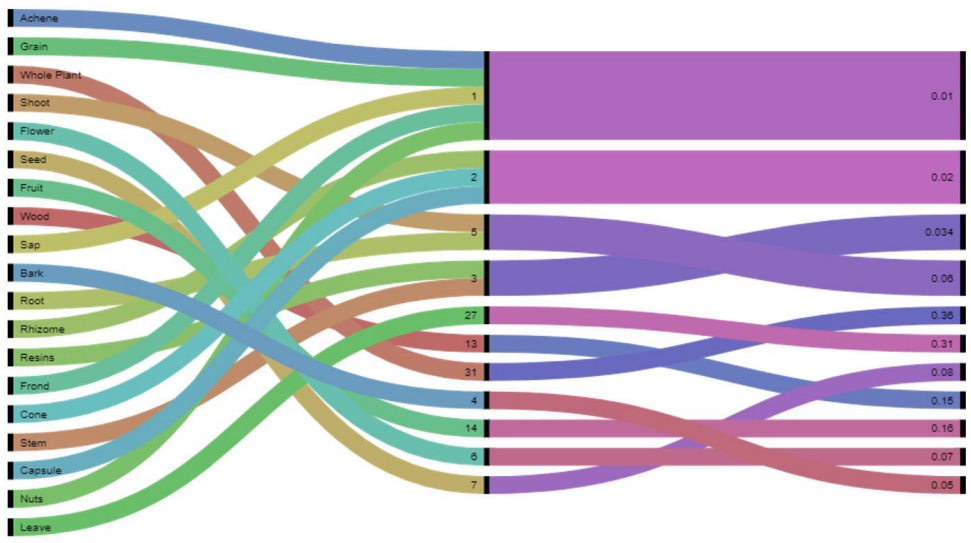

Figure 4. Part used of plant species by local informants and their percentages.
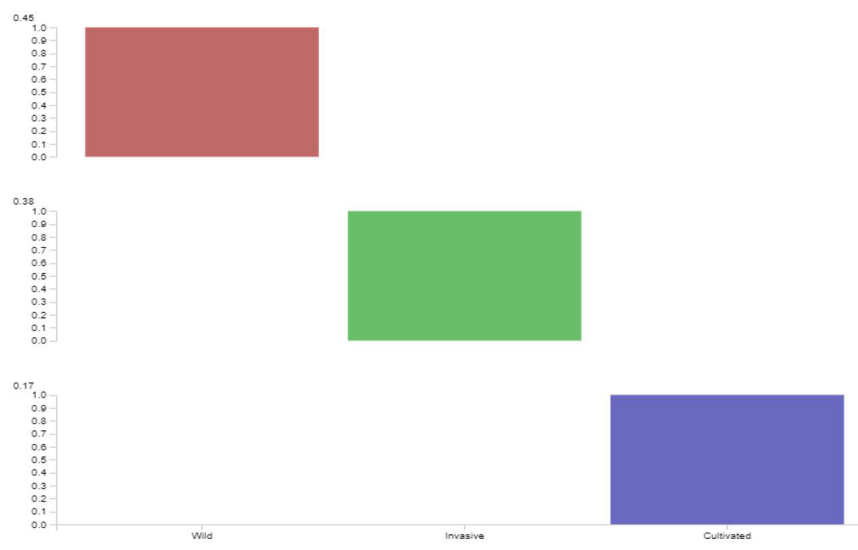

Figure 5 Nature of species in the local area.

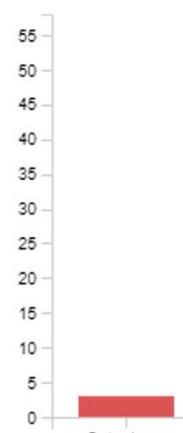

Cataplasm

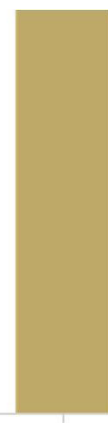

Decoction

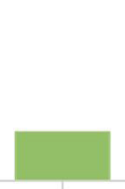

Extract

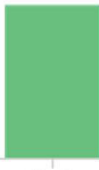

Fresh

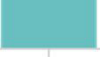

Infusion

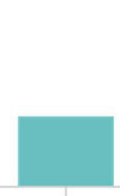

Juice

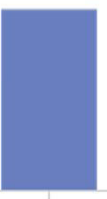

Maceration

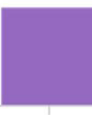

Paste

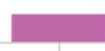

Pill

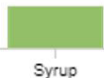

Figure 6 Form of preparation in local area. 
water, while (44.44\%) were prescribed for outer use as glue. The dominant parts of homegrown medications were set up from crisp plant material as opposed to dried material. The results show that large numbers of medicinal flora have been found to cure more than one disorder. Plant-like A. altissima, A. bracteosa, B. ciliate, C. intybus, M. azedarach, J. adhatoda, O. feroginia, P. somniferum, S. moorcroftiana, T. portulacastrum and $Z$. armatum were utilized for more than one disorder i.e. dysentery, diarrhea, cough, malaria, stomach ache, constipation, jaundice, cancer, fever, and seizures, which are very common in the reported area (Table 2). Various medicinal floras are used to treat such ailments by traditional healers (Simbo, 2010).

\subsection{New medicinal uses (Novelty)}

The current survey, reported 8 species, which were newly documented for their important medicinal uses these species include A. bracteosa (Blood purification, killing worms abdominal and intestine), I. rugosus (Expansive honey bee species), P. integrima Galls (Gas problems and Chest problems), N. officinale (Oil for relaxation of Knee Pain, increase sexual desire), M. azedarach, A. altissima and $A$. cepa (Inhabit biting swelling of various bees) and D. viscose (Wounds healing) Table 2. All these species have new uses in the local area. The plant species with new medicinal uses could be further studies to screen bioactive compounds and their phytochemical and pharmacological activities to introduce novel drugs, thus it provides fresh ethnomedicinal knowledge.

\subsection{Market Value in local area}

The local people of the area use indigenous medicinal flora for the treatment of many diseases and also sell many of them in the local market to earn their livelihood. About 7 medicinal plants were collected in the study area in Table 3, Figure 7. (Hamayun, 2007) also reported the important value of medicinal flora in National and International markets, corroborating what our report shows. Because many of the nomadic people and a large number of farmers in the mountains of the District Dir live near subsistence level, collection, and potentially cultivation, of these plants could become a more important source of supplementary income. The majority of the families in District Dir, in the area of our collection, are still living in poverty (Khan and Khan, 2011; Sher and Hussain, 2009). Our report showed that the native people of the research area are so poor that they are dependent for their survival on the medicinal flora, to sell in National and International Markets Table 3, Figure 7. Although medicinal flora collection has a huge value in the local market, collectors usually do not know how to market their products, or how much money they could be worth. They are not aware of the importance of their products as shown in (Shinwari and Qaisar, 2011). In the Swat Valley area, this is also true. Findings in (Shuaib et al., 2016) report of the sale and export of medicinal flora from district Dir to local markets and International markets of various countries i.e. India, Europe, Afghanistan, Iran, Arab countries, and Germany.

\subsection{Quantitative analysis of ethnobotanical data}

\subsubsection{Relative frequency citation (RFC)}

Relative frequency citation (RFC) was calculated to determine the most common medicinal plants used in the local area for various diseases. The value of RFC is ranged from (0.58) to (0.2) Table 2. The maximum RFC value is presented in A. sativum 0.58 , while the minimums value present in $P$. oleraceae 0.2 . The other maximum value represents in the species $L$. cylindrical (0.55), A. серa, $B$. lyceum (0.53), D. lotus, J. regia, C. sativm (0.53), M. nigra, $C$. pepo (0.52), O. sativa (0.50), A. altissima (0.47), S. tuberosum, M. alba, F. crica (0.46), P. somniferum (0.40), S. marianum, C. distans, B. campestris (0.39), M. azedarach, D. viscose (0.33), and M. denticulate (0.32) Table 2, Figure 8. The

Table 3. The important plant used to transport to local and international markets from Wari (Dir) Pakistan.

\begin{tabular}{|c|c|c|c|c|c|c|c|}
\hline S.No & Botanical name & $\begin{array}{l}\text { Local } \\
\text { name }\end{array}$ & Family & $\begin{array}{l}\text { Export } \\
\text { locally }\end{array}$ & $\begin{array}{c}\text { Export to } \\
\text { international } \\
\text { market }\end{array}$ & $\begin{array}{l}\text { Price per } \\
\quad \text { kg }\end{array}$ & $\begin{array}{c}\text { Amount } \\
\text { transport } \\
\text { per season }\end{array}$ \\
\hline 1 & $\begin{array}{c}\text { Pistacia integrrima .L. Stewart } \\
\text { ex Brand }\end{array}$ & Shanai & Anacardiaceae & $\begin{array}{l}\text { Lahore, } \\
\text { Peshawar }\end{array}$ & India & Rs. 1500 & $20,000 \mathrm{~kg}$ \\
\hline 2 & Zanthoxylum armatam DC. & Dambara & Rutaceae & $\begin{array}{l}\text { Peshawar, } \\
\text { Lahore }\end{array}$ & India & Rs.600 & $10,000 \mathrm{~kg}$ \\
\hline 3 & Valeriana jatamansi Jones & $\begin{array}{l}\text { Mushk- } \\
\text { e-bala }\end{array}$ & Valerianaceae & $\begin{array}{l}\text { Peshawar, } \\
\text { Lahore }\end{array}$ & Europe, India & Rs. 2000 & $20,000 \mathrm{~kg}$ \\
\hline 4 & Morchella esculenta Fr. & $\begin{array}{l}\text { Khossy. } \\
\text { Gochee }\end{array}$ & Morchellaceae & $\begin{array}{l}\text { Peshawar, } \\
\text { Lahore, } \\
\text { Karachi }\end{array}$ & India & Rs. 19,000 & $200 \mathrm{~kg}$ \\
\hline 5 & Rheum austral & Chootyal & Polygonaceae & $\begin{array}{l}\text { Peshawar, } \\
\text { Lahore }\end{array}$ & $\begin{array}{l}\text { India, Germany, } \\
\text { Iran }\end{array}$ & Rs.300 & $1000 \mathrm{~kg}$ \\
\hline 6 & Paeoniaemodi Wall.ex Royle & Mamekh & Paeoniaceae & $\begin{array}{l}\text { Peshawar, } \\
\text { Lahore }\end{array}$ & $\begin{array}{l}\text { India, Europe, } \\
\text { Germany }\end{array}$ & Rs.1800 & $1500-1800 \mathrm{~kg}$ \\
\hline 7 & Podophyllum hexandrum Royle & Kakorra & Podophyllaceae & $\begin{array}{l}\text { Peshawar, } \\
\text { Lahore }\end{array}$ & Europe, India & Rs. 300 & $11,000 \mathrm{~kg}$ \\
\hline
\end{tabular}




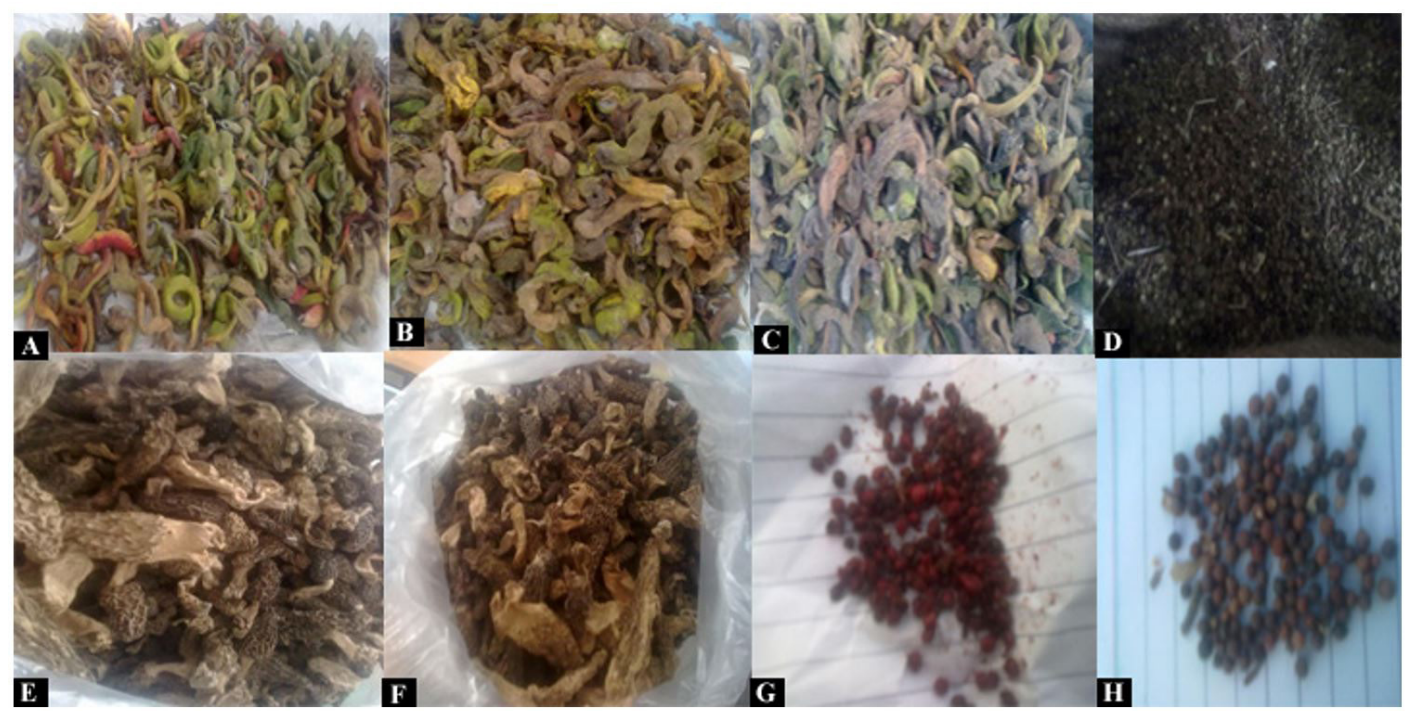

Figure 7. the important species which transport to local and international market of the world. Species (A) (B) \& (C) P. integrima (D) Z. armatum (E) and (F) M. esculenta (G) P. hexandrum and (H) R. austral.

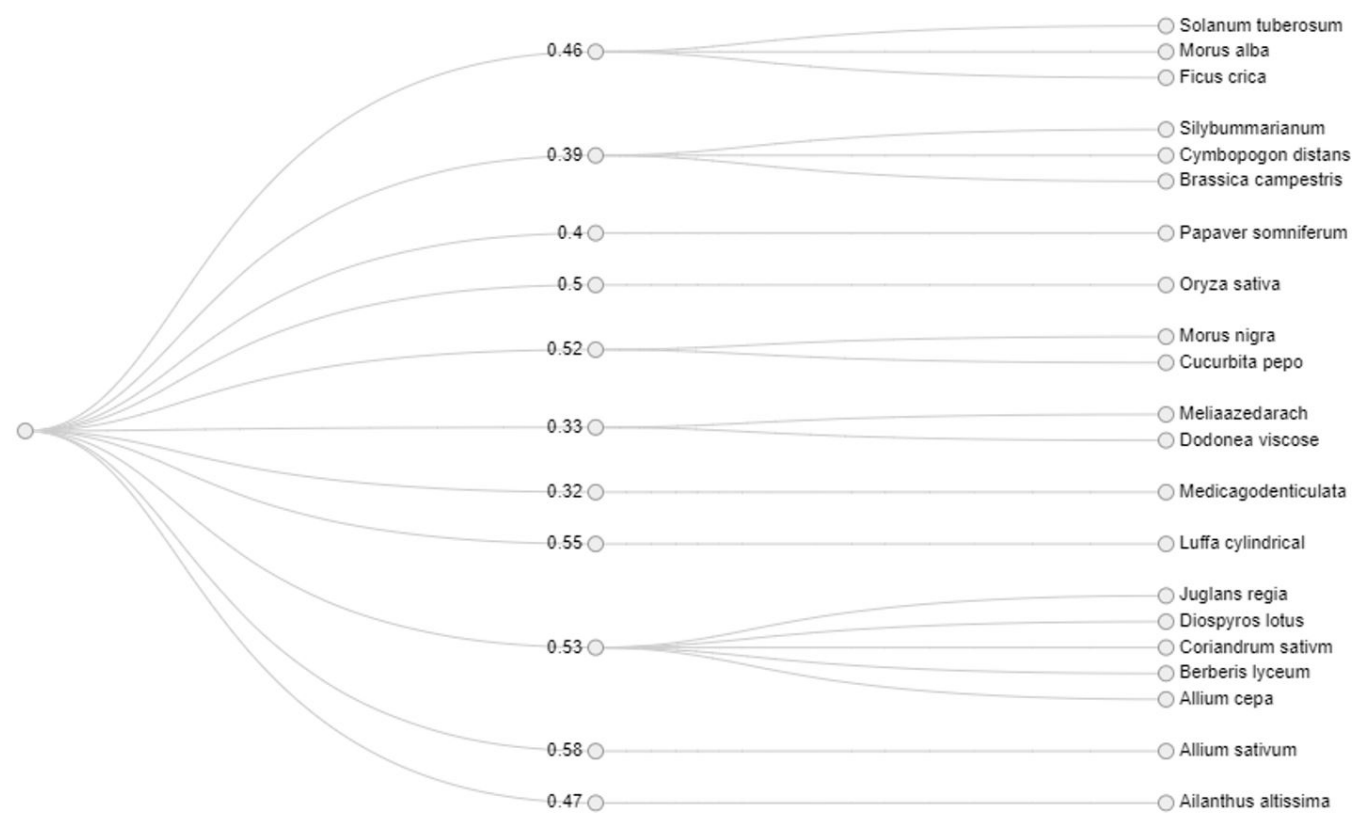

Figure 8. RFC value of medicinal plant using in the local area A. sativum L. shows highest values while M. denticulata shows the lowest RFC value.

maximum value means the most popular plants species in the community and local people are agreed with their uses. These species are important for daily uses like vegetables, medicinal and economic purposes. In terms of RFC, our values are parallel with (Ahmad et al., 2014; Shah et al., 2016)

\subsubsection{Use Value (UV)}

In the present study Use Value (UV) is ranged from 0.92 to 0.07 . The highest Use Value (UV) is recorded for J. adhatoda
(0.92) and the lowest UV is recorded for A. scoparia and $P$. integrima is 0.07 Table 2 . The other highest Used Value (UV) is C. sativm (0.86), J. regia, D. lotus (0.79), S. tuberosum, C. pepo (0.77), F. crica (0.73), B. lyceum (0.66), L. cylindrical (0.62), A. sativum, A. cepa (0.60), A. altissima (0.58), M. nigra (0.56), T. portulacastrum (0.55), P. somniferum, $O$. sativa (0.54), M. alba (0.52) and F. olivieri (0.50) Table 2. Plant with high Use Value means that the plant's species is used in other regions of Pakistan. The higher UV of the species also help in developing of drug after phytochemical 
screening and pharmacological studies in future, and some species have zero UV i.e. X. stumarium, T. terrestris, $P$. wallichiana, $V$. negundo, and some low-value species, $A$. scoparia, and P. integrima 0.07, A. fatua 0.09, Q. incana 0.10, it means the local informants were not familiar with the plant species and their medicinal uses. Some quantitative results are shown by (Shah et al., 2016) it is impossible to match our current results with the other area because it is the first quantitative ethnomedicinal data from tehsil Wari, Dir upper.

\subsubsection{Informant consensus factor (ICF)}

ICF was determined for 10 various aliments i.e. Stimulant, Gastrointestinal, Dermatitis, Diarrhea, Tonic, Anathematic, Astringent, Antiseptic, Expectorant, and antibacterial. The ICF value for these ailments is range from 0.71 to 0.92 in Figure 9. ICF value depends on the availability and uses of species in the area Figure 9. The maximum ICF value is recorded for diarrhea and dermatitis 0.92 , followed by gastrointestinal 0.90 , Stimulant and tonic each 0.88 , Anthelmintic 0.83 . The ICF value shows that Diarrhea and dermatitis are the most common diseases in the study area and the local peoples have more knowledge about the care of these two diseases. The plant species that uses for these two diseases are A. sativum, A. altissima, V. thapsus, S. moorcroftiana, P. lanceolata, R. crispus, P. somniferum, Q. incana, O. feroginia, N. officinale, J. adhatoda, E. prostrate, $D$. viscose, $C$. deodara, A. sativa, and A. cepa. These 16 plant species is not only used in local area for diarrhea and dermatitis but also used in other regions of Pakistan like
Swat (Akhtar et al., 2013), Lower Dir (Shuaib et al., 2014), Malakand (Barkatullah et al., 2015) Chitral and Khyber agency Peshawar (Ali et al., 2016). The minimum lowest ICF value is recorded for Biting (Astringent) and antibacterial (antiseptic) may this due to lack of communications and availability of species among the informants (Rajakumar and Shivanna, 2009).

\subsubsection{Fidelity level (FL)}

In our current study for Fidelity Level, we determined 10 Species that are used more by the local people. Generally FL of $100 \%$ for specific plants that all of the use reports mentions the same disease category (Srithi et al., 2009) In this study we have two species that have $100 \%$ FL value A. bracteosa and B. lyceum. The Fidelity Level FL value is ranged from (68\% to $100 \%$ ) in Figure 10. Maximum the value of FL more will the use of plant (Farnsworth, 1988). The maximum FL Value recorded for $A$. bracteosa and $B$. lyceum both each (100\%) followed by F. cretica (92\%), C. intybus (90.5\%), O. feroginia (86.36\%), P. emodi (76.93\%), and $M$. azedarach (75\%) in Figure 10. These plants are used by the informants for various diseases cure, the choice of informants dealing with the specific ailments that indicate a high FL value (Islam et al., 2014; Rajakumar and Shivanna, 2009).

\subsubsection{Jaccard index (JI) and comparison}

Jaccard index JI is used for comparison of our documented medicinal plant species of Tehsil Wari with the Allied near areas i.e. Kohistan valley, Sheringal valley,

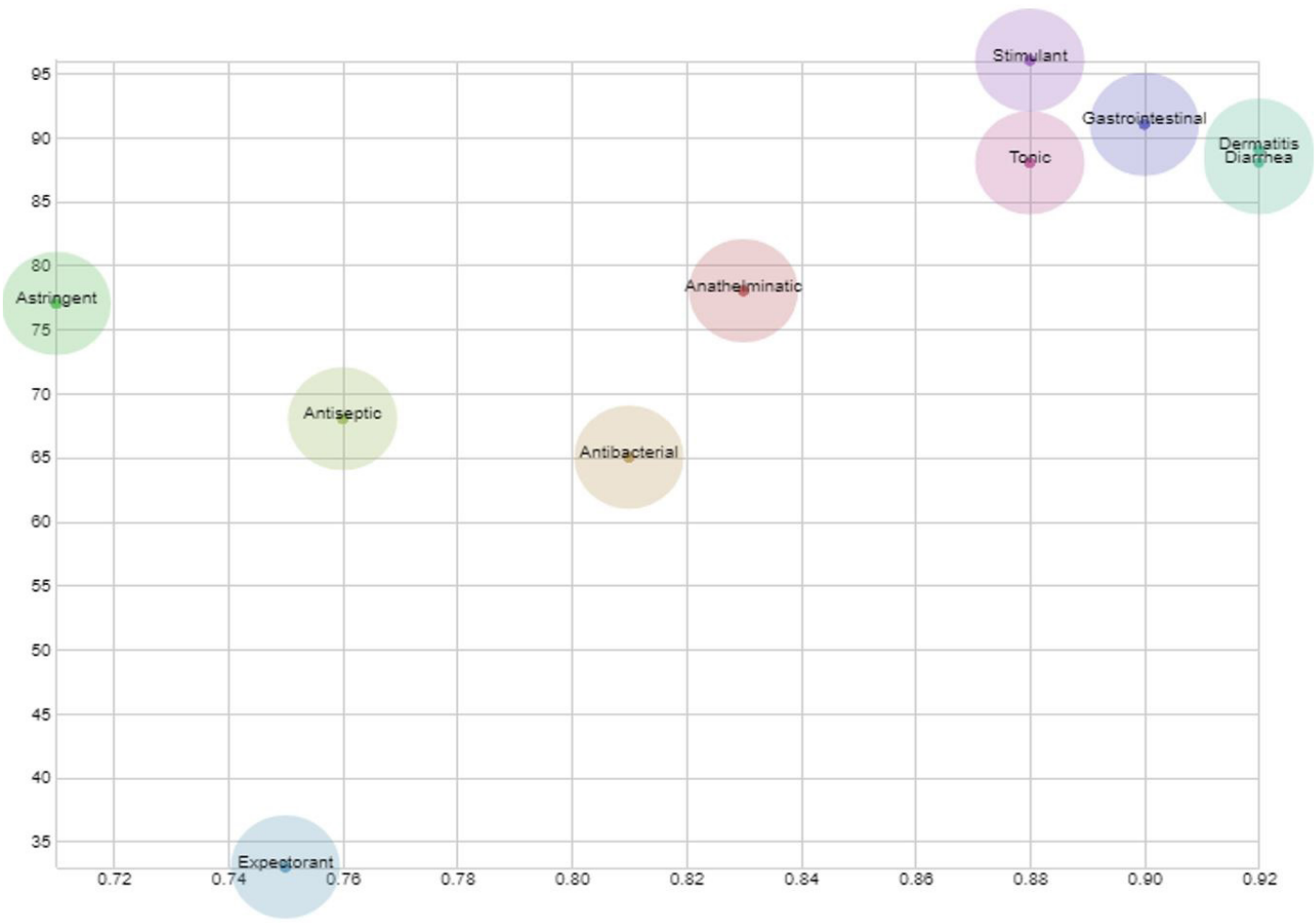

Figure 9. ICF values of traditional medicinal plants in local area. 


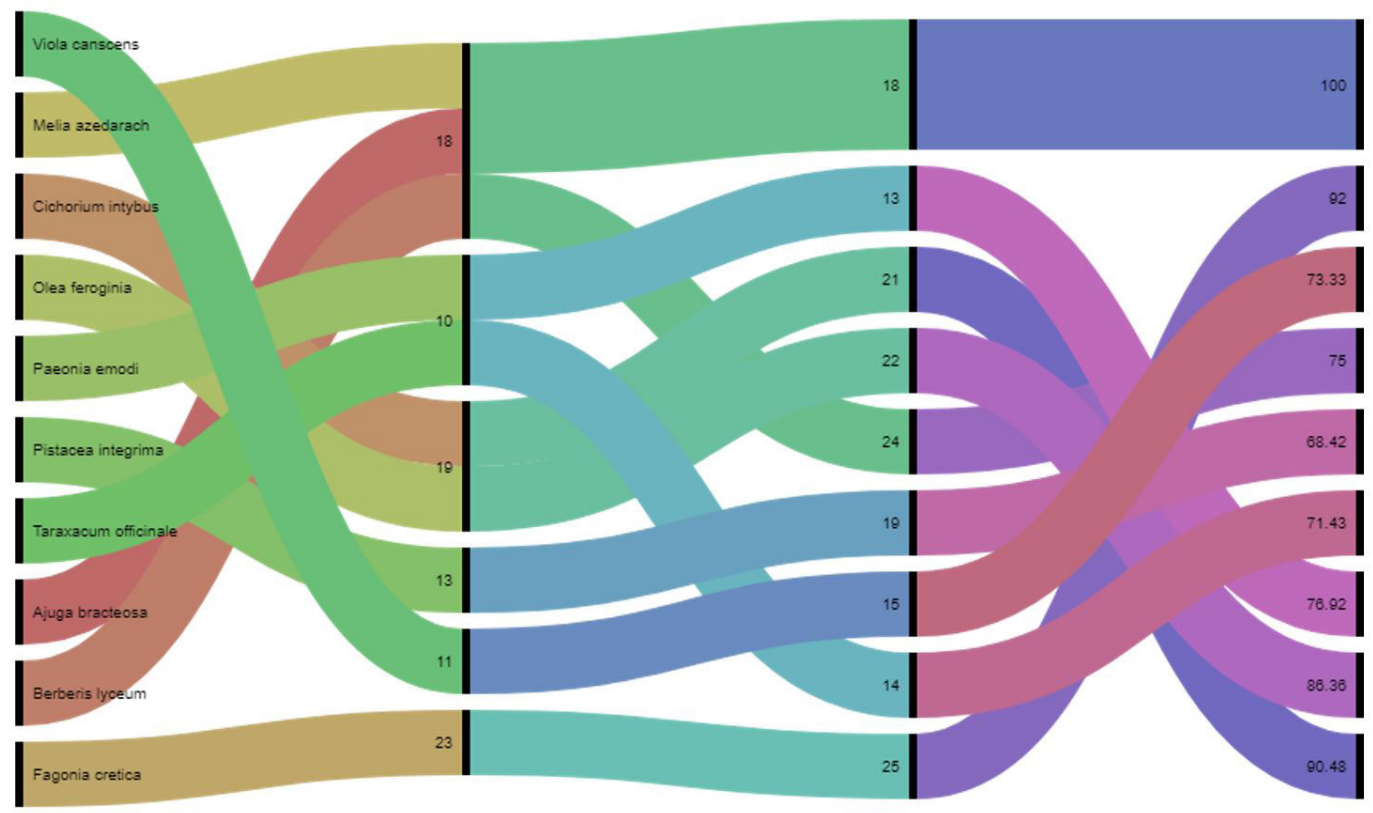

Figure 10. Fidelity level (FL) value of medicinal plants in local area highly used.

Chitral valley, Gilgit Baltistan, Swat valley, Malakand valley, Jandool valley, Lower Dir, Kabal Swat valley, Barawal valley, Bunner valley, Abbottabad, Khyber agency Peshawar, Mangowal, District Gujrat Panjab, and Hafizabad, Panjab. The highest Jaccard index JI value is recorded 29.8 and the lowest data is recorded is 4.72 Table 4 . The highest similarity is shown in 55 and the lowest is shown in 6 in Table 4.

The highest JI value is recorded 29.8, common species 55 , and similarly used species were 37 and dissimilar uses were 18 shown with our current results, from Buner valley (Sher et al., 2011) documented total 216 medicinal plants Table 4, the common species shown with our current results are $A$. pindrow, $A$. inciscum, $A$. vensutum, A. altissima, A. bracteosa, A. cepa, A. sativum, A. viridis, A. visnaga, $A$. scoparia, B. lyceum, B. ciliate, B. campestris, C. album, C. botrys, $C$. arvensis, C. sativm, C. distans, D. lotus, D. viscose, E. prostrate, F. crica, F. indica, F. indica, I. heterantha, J. regia, J. adhatoda, L. cylindrical, M. azedarach, M. esculenta, M. alba, M. nigra, N. tazzeta, N. officinale, O. feroginia, O. corniculata, $P$. emodi, P. roxburghii, P. wallichiana, P. integrima, P. lanceolata, $P$. oleraceae, $Q$. incana, $R$. hastatus, S. conidia, S. nigram, $S$. asper, T. officinale, T. terrestris, V. Thapsus, V. betonicifolia, $V$. negundo, W. somnifera, $X$. stumarium, and Z. armatum.

The lowest JI value is 4.72 recorded with (Hussain et al., 2011) Gilgit Baltistan. Total 47 records, 6 species are common, 2 species show similar uses and 4 species show dissimilar uses as shown in Table 4 . To compare the reported medicinal flora uses with the previous research work in allied areas of Pakistan, almost 75 species were found that have been mentions as herbal medicine but in the present research new medicinal uses of 11 plant species were reported for the first time. These 11 species belong to 10 different families that are Simarubaceae, Labiatae, Alliaceae, Moraceae, Meliaceae, Sapindaceae,
Iridaceae, Anacardiaceae, Polygonaceae, Brassicaceae. All the families present 1 species each except Labiatae which presented 2 species. The species were included $A$. Altissima which were reported for the honey bees visited for making honey which showed similar with (Jan et al., 2011). But the new medicinal uses which are reported for the first time of this species is Plant leave is used as cataplasm on swelling after biting a yellow fly.

A. bracteosa were heated in water and use for blood purification, reduce stomach acidity, headache and measles which were same with (Hazrat et al., 2011) for the first time it used for blood purification, Killing worms abdominal and intestine.

A. cepa is used as a vegetable, salad and also in skin problems. The bulbs are crushed and paste on boils (Hussain et al., 2011). The new significant medicinal uses of its bulbs layers of an onion for the swelling of biting skins by various bees.

D. viscose plant used for ornamental, making broom ash of leaves used in snuff. But for the medicinally use as rheumatism, astringent and swelling (Shah et al., 2016). The fresh leave is used as bandages in the past which is reported for the first time.

$F$. crica were helped in controlling sugar, cancer, emollient, laxative and demulcent while also is used for thalassemia, carminative, stomachic, constipation (Shah et al., 2016). While the wood used as fuel, Sap also helps in controlling vitiligo disease which was not reported by the other researcher.

I. rugosus Extract sprayed in houses to kills fleas and termites. Leave is used for cleaning teeth and fodder for animals. A decoction of the herb is used for curing sore throat; coughing, hepatitis $B$, and $C$. Leaves help in remove fungal infection of the mouth. Also used as a fuel and 
Table 4. Comparison of medicinal plant species of Tehsil Wari with the Allied near areas using Jacord Index.

\begin{tabular}{|c|c|c|c|c|c|c|c|c|}
\hline S.No & References & Area & $\begin{array}{l}\text { Year of } \\
\text { study }\end{array}$ & $\begin{array}{l}\text { Number } \\
\text { of spp. } \\
\text { Recorded }\end{array}$ & $\begin{array}{l}\text { Common } \\
\text { species in } \\
\text { Both }\end{array}$ & $\begin{array}{l}\text { Similar } \\
\text { use of } \\
\text { species }\end{array}$ & $\begin{array}{l}\text { Plant having } \\
\text { dissimilarity }\end{array}$ & $\begin{array}{c}\text { Jaccard } \\
\text { index (JI) }\end{array}$ \\
\hline 1 & (Jan et al., 2011) & $\begin{array}{l}\text { Kohistan valley, KP, } \\
\text { Pakistan }\end{array}$ & 2011 & 65 & 25 & 9 & 16 & 19.8 \\
\hline 2 & (Hazrat et al., 2011) & $\begin{array}{c}\text { Sheringal valley KP, } \\
\text { Pakistan }\end{array}$ & 2011 & 62 & 24 & 16 & 8 & 19.5 \\
\hline 3 & (Ali and Qaiser, 2009) & $\begin{array}{l}\text { Chitral valley, } \\
\text { Pakistan }\end{array}$ & 2009 & 83 & 9 & 03 & 06 & 5.62 \\
\hline 4 & (Hussain et al., 2011) & $\begin{array}{l}\text { Gailgit Baltistan, } \\
\text { Pakistan }\end{array}$ & 2011 & 47 & 6 & 02 & 04 & 4.72 \\
\hline 5 & (Akhtar et al., 2013) & $\begin{array}{l}\text { Swat valley KP, } \\
\text { Pakistan }\end{array}$ & 2013 & 96 & 33 & 19 & 14 & 22.1 \\
\hline 6 & (Barkatullah et al., 2015) & $\begin{array}{l}\text { Malakand valley } \\
\text { KP, Pakistan }\end{array}$ & 2015 & 92 & 33 & 24 & 09 & 22.7 \\
\hline 7 & (Nisar and Ali, 2012) & $\begin{array}{c}\text { Jandool valley KP, } \\
\text { Pakistan }\end{array}$ & 2012 & 67 & 31 & 18 & 13 & 25.4 \\
\hline 8 & (Shuaib et al., 2014) & $\begin{array}{l}\text { Lower Dir KP, } \\
\text { Pakistan }\end{array}$ & 2014 & 40 & 29 & 21 & 08 & 29.8 \\
\hline 9 & (Ahmad et al., 2011) & $\begin{array}{l}\text { Kabal, Swat valley } \\
\text { KP, Pakistan }\end{array}$ & 2011 & 140 & 38 & 20 & 18 & 20.2 \\
\hline 10 & (Khan et al., 2016) & $\begin{array}{l}\text { Barawal valley } \\
\text { Upper Dir KP, } \\
\text { Pakistan }\end{array}$ & 2016 & 64 & 19 & 16 & 03 & 14.5 \\
\hline 11 & (Sher et al., 2011) & $\begin{array}{l}\text { Bunner valley KP, } \\
\text { Pakistan }\end{array}$ & 2011 & 216 & 55 & 37 & 18 & 22.2 \\
\hline 12 & (Kayani et al., 2014) & $\begin{array}{l}\text { Abbatabad, KP, } \\
\text { Pakistan KP, } \\
\text { Pakistan }\end{array}$ & 2014 & 120 & 20 & 08 & 12 & 10.76 \\
\hline 13 & (Ali et al., 2016) & $\begin{array}{c}\text { Khyber agency } \\
\text { Peshawar, Pakistan }\end{array}$ & 2016 & 31 & 09 & 05 & 04 & 8.333 \\
\hline 14 & (Parvaiz, 2014) & $\begin{array}{l}\text { Mangowal, District } \\
\text { Gujrat Panjab, } \\
\text { Pakistan }\end{array}$ & 2014 & 40 & 06 & 02 & 04 & 5 \\
\hline 15 & (Umair et al., 2017) & $\begin{array}{l}\text { Hafizabad, Panjab, } \\
\text { Pakistan }\end{array}$ & 2017 & 85 & 13 & 06 & 07 & 8.2 \\
\hline
\end{tabular}

urgent Snuff (Khan et al., 2016). The new medicinal is The flower was used in making honey, the most expensive honey is of I. rugosus which 3000 per Kg. Leaves help in to remove the fungal infection of the mouth. Also used as a fuel and urgent Snuff.

I. ensata plants were used as a blood purifier (Khan et al., 2016). While the first time it is reported for the making local green rice

M. azedarach leaves were used as fodder. Leaves are also used for biting place. A bark is heating in water and used for dysentery, emetic and cathartic. Wood is used as fuel and wood products. The plant is used for burns, gonorrhea, gingivitis, piles, headache, diabetes, pyrexia, and spleen enlargement (Rehman et al., 2013). The first time its leave is used for swelling after biting of yellow fly biting.

$N$. officinale leaves are used as a vegetable, a salad which helps tetanus (Khan et al., 2016; Khan et al., 2009). The new medicinal uses of this plant for the first time that oil is extracted from the seed and used (Massage) relaxing Body muscles and increase sexual desire.

$P$. integrima barks are boiled and its extract is used for the bronchial disorder (Ahmad et al., 2014) while its unknown medicinal uses are introducing is its gall is used for gas and chest problem.

$R$. crispus leaves are used as vegetable and fodder for animals. Fruit help in digestion and is mostly used in condiments (Hussain et al., 2011) while it is introduced in the treatment of ear-burning infection special its spore powder.

The people of that research area mostly utilized herbs and trees for ethnological purposes and the result is in line with our research (Habib-Ul-Hassan et al., 2015). The majority of plants utilized for medicinal purposes in the research area are herbaceous plants. The informants 
felt it takes more time and effort to harvest plants from woody medicinal flora. This could also relate to the fact that herbaceous plants are more easily accessible in the nearby areas, than trees and shrubs. The dominant use of herbaceous material as medicinal flora in our research agrees with other ethnobotanical research into medicinal flora inventories, done in Pakistan, and in the entire world (Adnan et al., 2012; Giday et al., 2010; Ibrar and Hussain, 2009; Murad et al., 2011; Yineger et al., 2007) reported on ethnobotanical studies of medicinal flora of Batkhela district which were in line with the research. This study examined what parts of the medicinal flora were utilized for various purposes. The local people mostly harvest the whole plant for ethnobotanical purposes. Harvesting the whole plant greatly reduces the number of plants in existence, and causes a great threat of extinction to these medicinal floras. Harvesting the medicinal flora in excess may destroy the sustainable utilization of this highly valued plant biodiversity. Our research is in line with an ethnobotanical survey of Naran Valley, Pakistan (Khan et al., 2013b). Leaves are used more frequently in the research area. The huge utilization of the leaves may be due to the easy availability. The excessive utilization of leaves might also be due to great medicinal value but more research is required to explore their medicinal properties (Barkatullah and Ibrar, 2011). The uses of leaves for medicinal value (Habib-Ul-Hassan et al., 2015) have been reported on as being a greater source of medicine than the present research shows. The frequent utilization of leaves is also reported on by various other ethnobotanists (Barkatullah and Ibrar, 2011).

This may be because some medicinal flora contains large numbers of secondary metabolites (Tolossa et al., 2013) and (Habib-Ul-Hassan et al., 2015) also report the same single species being used for various disorders in the same way as our present findings. The majority of medicinal recipes are taken orally in the research area. That may be because of the ease of utilization of additives like honey, milk, etc. as a carrier for administration of the remedies. This was also reported in (Lulekal et al., 2013) that oral ingestion was the preferred mode of administration of plant remedies. (Murad et al., 2013; Ullah et al., 2006) also reported the same result. The medicinal flora of the study area is facing many threats of over-exploitation, like overgrazing, use as construction material, and the use for fuel and food. The native people of the area are very poor and the majority of these people are involved in collecting and exploiting plants for their needs, and the needs of their cattle. The grazing of their cattle is causing great damage to the medicinal flora of the research area. (Lulekal et al., 2013) also, many medicinal floras are shown to be over-exploited in our report. The most common fuel and fodder plants are A. altissima, C. deodara, D. viscose, F. crica, I. heterantha, M. azedarach, O. feroginia, P. roxburghii, $Q$. baloot, $Q$. incana. Due to the shortage of modern sources of fuel, the native people are over-harvesting the woody species to fulfill their basic heating requirements, without any awareness of their role in pushing the woody plants towards extinction. It was noticed that pressure on fuel woods increased greatly in winter because of cold weather. This finding is also reported in (Ahmed et al., 2013) Woody species from New Murree was used as fuel, as shown in the present report. Our survey shows that a huge number of medicinal floras are over-harvested for ethnobotanical purposes. Agriculture and livestock rearing in the research area is also a very common practice. This supports the lives of rural people. Another pressure on the medicinal flora of the survey area is overgrazing, with animals trampling the ground and causing soil compaction. Compacted soil retards germination, and slows seed growth and development. (Nogués-Bravo et al., 2008) reports the same result. Moreover, the rearing of goats is very common in the survey area, which causes huge damage to the flora through browsing. (Murad et al., 2013) reports the same effect of the animals as shown in our findings.

\subsection{Future impact of the study}

We hope this study will be valuable to develop a sense in the local communities, of the value economically and social of the local medicinal plants, and encourage them to care for them, for future generations. This valuable information hopefully will also encourage the local inhabitants to preserve the beauty of their valley. This can lead to increased tourism, which could have a positive effect on the local economy. With tourism could come to a greater awareness of the value and importance of the local medicinal plants, and lead to their marketing and export to the different countries of the world? That would also improve the local economy.

\section{Conclusion}

There is a great relationship between plants and humans. Plants play a vital role in the life of humans. Human life is impossible without plants. Plants are necessary to balance ecosystems. Plants trap the sunlight and create energy and then transfer it to animals and humans. All life forms on Earth depend on plant energy. The Wari Valley in Northern Pakistan is rich in plants with economic, commercial, pharmaceutical, medicinal and ethnobotanical uses. We hope our research work will generate widespread interest in the local communities to protect and conserve the medicinal flora for future generations. The native people of Dir Upper Wari have been dependent on medicinal plants to fulfill their day-to-day health care needs. The traditional healers and herbalists have centuries-old knowledge, about the uses of plants. The local inhabitants know some of the uses for plants, but they don't know the proper ways of the collection, collection time, parts used preservation and proper storage. The local area has an illiterate population, with poor ways of plant collection, unscientific ways of storage of medicinal plants, corrupt forest officials, with the smuggling of timber wood. These were big factors that could lead to the extinction of many medicinal plants. Many plant species are at risk due to over-collection in the local area. The important and high-value plants are decreasing in number and could become extinct. Education in proper ways of collection and conservation could lead to the preservation of these valuable plants for future generations. Medicinal plants are an important component in the agriculture sector and contribute a great share in the economic development of a country. 


\section{Acknowledgements}

We all authors are very thankful to the local peoples, herbalists and markets dealers, who shared their precious knowledge with us for the future conservation of important flora in the local area. Special thanks to the anonymous reviewers for their valuables comments.

\section{References}

ABBASI, A.M., KHAN, M.A., AHMAD, M., QURESHI, R., ARSHAD, M. JAHAN, S., ZAFAR, M. and SULTANA, S., 2010. Ethnobotanical study of wound healing herbs among the tribal communities in Northern Himalaya Ranges District Abbottabad, Pakistan. Pakistan Journal of Botany, vol. 6, pp. 3747-3753.

ADNAN, M., BEGUM, S., KHAN, A.L., TAREEN, A.M. and LEE, I.-J., 2012. Medicinal plants and their uses in selected temperate zones of Pakistani Hindukush-Himalaya. Journal of Medicinal Plants Research, vol. 6, no. 24, pp. 4113-4127.

AFZAL, S., AFZAL, N., AWAN, M.R., KHAN, T.S., KHANUM, A.G. and TARIQ S., 2009. Ethno-botanical studies from Northern Pakistan. Journal of Ayub Medical College, Abbottabad, vol. 21, no. 1, pp. 52-57. PMid:20364741.

AHMAD, I., IBRAR, M. and ALI, N., 2011. Ethnobotanical study of Tehsil Kabal, Swat District, KPK. Pakistan Journal of Botany, vol. 2011, pp. 1-8. http://dx.doi.org/10.1155/2011/368572.

AHMAD, M., KHAN, M.A. and QURESHI, R.A., 2003. Ethnobotanical study of some cultivated plants of Chhuch region [District Attock]. Hamdard Medicus, vol. 46, no. 3, pp. 5-19.

AHMAD, M., SULTANA, S., FAZL-I-HADI, S., BEN HADDA, T., RASHID, S., ZAFAR, M., KHAN, M.A., KHAN, M.P. and YASEEN, G., 2014. An Ethnobotanical study of Medicinal Plants in high mountainous region of Chail valley (District Swat-Pakistan). Journal of Ethnobiology and Ethnomedicine, vol. 10, no. 1, pp. 36. http://dx.doi.org/10.1186/1746-4269-10-36. PMid:24739524.

AHMED, E., ARSHAD, M., SABOOR, A., QURESHI, R., MUSTAFA, G., SADIQ S. and CHAUDHARI, S.K., 2013. Ethnobotanical appraisal and medicinal use of plants in Patriata, New Murree, evidence from Pakistan. Journal of Ethnobiology and Ethnomedicine, vol. 9, no. 1, pp. 13. http://dx.doi.org/10.1186/1746-4269-9-13. PMid:23445756.

AKHTAR, N., RASHID, A., MURAD, W. and BERGMEIER, E., 2013. Diversity and use of ethno-medicinal plants in the region of Swat, North Pakistan. Journal of Ethnobiology and Ethnomedicine, vol. 9, no. 1, pp. 25. http://dx.doi.org/10.1186/1746-4269-9-25. PMid:23587127.

ALI, H. and QAISER, M., 2009. The ethnobotany of Chitral valley, Pakistan with particular reference to medicinal plants. Pakistan Journal of Botany, vol. 41, no. 4, pp. 2009-2041.

ALI, K., AKHTAR, N., SHUAIB, M., ALI, S., GHAFFAR, A., SHAH, M., KHAN, A., HUSSAIN, F., KHAN, Z., KALEEM, I., NAZIR, A. and IQBAL, M., 2019a. Impact of Urbanization on Vegetation: a Survey of Peshawar, Pakistan. Polish Journal of Environmental Studies, vol. 28, no. 4, pp. ‥ http://dx.doi.org/10.15244/pjoes/89609.

ALI, K., SHUAIB, M., HUSSAIN, Z., SAJJAD, W., ALI, F. and FAZIL, M., 2016. Ethnobotanical assessment of the medicinal flora of Khyber agency, Pakistan. Pakistan Journal of Weed Science Research, vol. 22, no. 4, pp. 607-616.

ALI, K., SHUAIB, M., MALIK, T., SHAH, S.S., ALI, S., SHAH, N.A., HUSSAIN, F., KHAN, I., AKHTAR, N. and LI, Z., 2019b. Urban Sprawl and its Impact on Soil and Plant Species in Peshawar,
Pakistan. Polish Journal of Environmental Studies, vol. 28, no. 4, pp. 2041-2048. http://dx.doi.org/10.15244/pjoes/91844.

ALI, S. and QAISER, M., 1993. Flora of Pakistan (fascicle series) Islamabad. Karachi: University of Karachi, pp. 2000-2008.

AWAN, M.R., IQBAL, Z., SHAH, S.M., JAMAL, Z., JAN, G., AFZAL, M., MAJID, A. and GUL, A., 2011. Studies on traditional knowledge of economically important plants of Kaghan Valley, Mansehra District, Pakistan. Journal of Medicinal Plants Research, vol. 5, no. 16, pp. 3958-3967.

BARKATULLAH, B. and IBRAR, M., 2011. Plants profile of Malakand Pass Hills, District Malakand, Pakistan. African Journal of Biotechnology, vol. 10, no. 73, pp. 16521-16535. http://dx.doi. org/10.5897/AJB11.1258.

BARKATULLAH, IBRAR, M., RAUF, A., BEN HADDA, T., MUBARAK, M.S. and PATEL, S., 2015. Quantitative ethnobotanical survey of medicinal flora thriving in Malakand Pass Hills, Khyber Pakhtunkhwa, Pakistan. Journal of Ethnopharmacology, vol. 169, pp. 335-346. http://dx.doi.org/10.1016/j.jep.2015.04.052. PMid:25952168.

BARTH, F., 1981. Process and form in social life. London: Routledge Kegan \& Paul.

BEGUM, H., JAN, M.M. and HUSSAIN, F., 2005. Ethnobotanical studies on some medicinal plants of Dehri Julagram, Malakand Agency, Pakistan. International Journal of Biotechnology, vol. 2, pp. 597-602.

DURRANI, M.J., RAZAQ A., MUHAMMAD, S.G., HUSSAIN, F., 2010. Floristic diversity, ecological, characteristics and ethnobotonical profile of plants of aghberg rangelands, Balochistan, Pakistan. Pakistan Journal of Plant Sciences, vol. 16, no. 1, pp. 26-33.

FARNSWORTH, N.R., 1988. Screening plants for new medicines. Biodiversity (Nepean), vol. 3, pp. 81-99.

FAROOQ S., BARKI, A., YOUSAF KHAN, M. and FAZAL, H., 2012. Ethnobotanical studies of the flora of tehsil Birmal in South Waziristan Agency, Pakistan. Pakistan Journal of Weed Science Research, vol. 18, no. 3, pp. 277-291.

FRIEDMAN, J., YANIV, Z., DAFNI, A. and PALEWITCH, D., 1986. A preliminary classification of the healing potential of medicinal plants, based on a rational analysis of an ethnopharmacological field survey among Bedouins in the Negev Desert, Israel. Journal of Ethnopharmacology, vol. 16, no. 2-3, pp. 275-287. http:// dx.doi.org/10.1016/0378-8741(86)90094-2. PMid:3747566.

GIDAY, M., ASFAW, Z. and WOLDU, Z., 2010. Ethnomedicinal study of plants used by Sheko ethnic group of Ethiopia. Journal of Ethnopharmacology, vol. 132, no. 1, pp. 75-85. http://dx.doi. org/10.1016/j.jep.2010.07.046. PMid:20674734.

GILANI, A.H. and ATTA-UR-RAHMAN, 2005. Trends in ethnopharmacology. Journal of Ethnopharmacology, vol. 100, no. 1-2, pp. 43-49. http://dx.doi.org/10.1016/j.jep.2005.06.001. PMid: 16127805.

HABIB-UL-HASSAN, W.M., AHMAD, N., TARIQ A., KHAN, I., AKHTAR, N. and JAN, S., 2015. Indigenous uses of the plants of Malakand valley, district Dir (Lower), Khyber Pakhtunkhwa, Pakistan. Pakistan Journal of Weed Science Research, vol. 21, no. 1, pp. 83-99.

HAMAYUN, M., 2003. Ethnobotanical studies of some useful shrubs and trees of District Buner, NWFP, Pakistan. Ethnobotanical Leaflets, vol. 2003, no. 1, pp. 12.

HAMAYUN, M., 2007. Traditional uses of some medicinal plants of Swat Valley, Pakistan. Indian Journal of Traditional Knowledge, vol. 6, no. 4, pp. 636-641.

HAZRAT, A., SHAH, J. and NISAR, M., 2011. Medicinal plants of Sheringal Valley, Dir Upper, KPK, Pakistan. FUUAST Journal of Biology, vol. 1, no. 2, pp. 131. 
HUSSAIN, I., BANO, A. and ULLAH, F., 2011. Traditional drug therapies from various medicinal plants of central karakoram national park, Gilgit-Baltistan Pakistan. Pakistan Journal of Botany, vol. 43, pp. 79-84.

HUSSAIN, J., KHAN, A.L., REHMAN, N., HAMAYUN, M., SHAH, T., NISAR, M., BANO, T., SHINWARI, Z.K. and LEE, I., 2009. Proximate and nutrient analysis of selected vegetable species: a case study of Karak region, Pakistan. African Journal of Biotechnology, vol. 8, no. 12, pp. 2275-2729.

HUSSAIN, W., ULLAH, A., HUSSAIN, J., HUSSAIN, S., SHINWARI, Z.K., and IBRAR, M., 2014. Ethno-medicinal plants of Tahsil Barawal Bandi Dir Upper Khyber Pakhtunkhwa Pakistan. Journal of Applied Pharmaceutical Science, vol. 4, no. 7, pp. 094-097.

IBRAR, M. and HUSSAIN, F., 2009. Ethnobotanical studies of plants of Charkotli hills, Batkhela district, Malakand, Pakistan. Frontiers of Biology in China, vol. 4, no. 4, pp. 539-548. http://dx.doi. org/10.1007/s11515-009-0045-2.

IBRAR, M., HUSSAIN, F. and SULTAN, A., 2007. Ethnobotanical studies on plant resources of Ranyal hills, District Shangla, Pakistan. Pakistan Journal of Botany, vol. 39, no. 2, pp. 329.

ISLAM, M.K., SAHA, S., MAHMUD, I., MOHAMAD, K., AWANG, K., UDDIN, S.J., RAHMAN, M.M. and SHILPI, J.A., 2014. An ethnobotanical study of medicinal plants used by tribal and native people of Madhupur forest area, Bangladesh. Journal of Ethnopharmacology, vol. 151, no. 2, pp. 921-930. http://dx.doi. org/10.1016/j.jep.2013.11.056. PMid:24342778.

ISMAIL, S. and NISAR, M.F., 2010. Ethnomedicinal survey for important plants of district Lodhran, Punjab, Pakistan. BIOL (E-Journal of Life Sciences), vol. 1, no. 3, pp. 52-58.

JAN, G., KHAN, M.A., FARHATULLAH, J.F., AHMAD, M., JAN, M. and ZAFAR, M., 2011. Ethnobotanical studies on some useful plants of Dir Kohistan valleys, KPK, Pakistan. Pakistan Journal of Botany, vol. 43, no. 4, pp. 1849-1852.

KADAM, P. and BHALERAO, S., 2010. Sample size calculation. International Journal of Ayurveda Research, vol. 1, no. 1, pp. 55-57. http://dx.doi.org/10.4103/0974-7788.59946. PMid:20532100.

KAYANI, S., AHMAD, M., ZAFAR, M., SULTANA, S., KHAN, M.P.Z., ASHRAF, M.A., HUSSAIN, J. and YASEEN, G., 2014. Ethnobotanical uses of medicinal plants for respiratory disorders among the inhabitants of Gallies-Abbottabad, Northern. Pakistan. Journal of Ethnopharmacology, vol. 156, pp. 47-60. http://dx.doi. org/10.1016/j.jep.2014.08.005. PMid:25153021.

KEW SCIENCE WCSP,2021 [viewed 18 August 2021]. 'World Checklist of Selected Plant Families. Facilitated by the Royal Botanic Gardens, Kew. Available from: http://wcsp.science.kew.org/ http://apps. kew.org/wcsp/home.

KHAN, A. and KHAN, J., 2011. Market Survey of Useful Plants in the Mountain Region of Abbottabad District, Pakistan. World Applied Sciences Journal, vol. 14, no. 4, pp. 510-513.

KHAN, A.A., ALI, F., IHSAN, M., HAYAT, K. and NABI, G., 2015. Ethnobotanical study of the medicinal plants of Tehsil Charbagh, district Swat, Khyber Pakhtunkhwa, Pakistan. AmericanEurasian Journal of Agricultural \& Environmental Sciences, vol. 15, pp. 1464-1474.

KHAN, M.T., KHAN, I., KHAN, M.I., HUSSAIN, Z., AYUB, S., KHAN, N., SHUAIB, M. and KHAN, I.A., 2016. Ethnobotanical study of wild flora in the remote areas of Nothern Pakistan. Wulfenia Journal, vol. 23, pp. 10, pp. 149-165.

KHAN, N., AHMED, M., AHMED, A., SHAUKAT, S., WAHAB, M., AJAIB, M., SIDDIQUI, M.F. and NASIR, M., 2011. Important medicinal plants of chitral gol National park (cgnp) Pakistan. Pakistan Journal of Botany, vol. 43, no. 2, pp. 797-809.
KHAN, R.U., MEHMOOD, S., KHAN, S.U., and JAFFAR, F., 2013a. Ethnobotanical study of food value flora of district Bannu Khyber Pakhtunkhwa, Pakistan. Journal of Medicinal Plants Studies, vol. 1, no. 4, pp. 93-106.

KHAN, S.M., PAGE, S., AHMAD, H., SHAHEEN, H., ULLAH, Z., AHMAD, M. and HARPER, D.M., 2013b. Medicinal flora and ethnoecological knowledge in the Naran Valley, Western Himalaya, Pakistan. Journal of Ethnobiology and Ethnomedicine, vol. 9, no. 1, pp. 4. http://dx.doi.org/10.1186/1746-4269-9-4. PMid:23302393.

KHAN, S.A., JAVED, N., KHAN, M.A., KAMRAN, M. and ATIF, H.M., 2009. Effects of plant extracts on egg hatch and larval morality of Meloidogyne incognita. Pakistan Journal of Phytopathology, vol. 20, pp. 204-208.

LULEKAL, E., ASFAW, Z., KELBESSA, E. and VAN DAMME, P., 2013. Ethnomedicinal study of plants used for human ailments in Ankober District, North Shewa Zone, Amhara region, Ethiopia. Journal of Ethnobiology and Ethnomedicine, vol. 9, no. 1, pp. 63. http://dx.doi.org/10.1186/1746-4269-9-63. PMid:23984919.

MAURI, M., ELLI, T., CAVIGLIA, G., UBOLDI, G. and AZZI, M., 2017. RAWGraphs: a visualisation platform to create open outputs. In: Proceedings of the 12th Biannual Conference on Italian SIGCHI Chapter; 2017; Cagliari, Italy. New York: ACM, pp. 28:1-28:5. http://dx.doi.org/10.1145/3125571.3125585.

MURAD, W., AHMAD, A., GILANI, S.A. and KHAN, M.A., 2011. Indigenous knowledge and folk use of medicinal plants by the tribal communities of Hazar Nao Forest, Malakand District, North Pakistan. Journal of Medicinal Plants Research, vol. 5, no. 7, pp. 1072-1086.

MURAD, W., AHMAD, A., ISHAQ G., SALEEM KHAN, M., MUHAMMAD KHAN, A., ULLAH, I. and KHAN, I., 2012. Ethnobotanical studies on plant resources of Hazar Nao forest, district Malakand, Pakistan. Pakistan Journal of Weed Science Research, vol. 18, no. 4, pp. 509-527.

MURAD, W., AZIZULLAH, A., ADNAN, M., TARIQ A., KHAN, K.U., WAHEED, S. and AHMAD, A., 2013. Ethnobotanical assessment of plant resources of Banda Daud Shah, District Karak, Pakistan. Journal of Ethnobiology and Ethnomedicine, vol. 9, no. 1, pp. 77. http://dx.doi.org/10.1186/1746-4269-9-77. PMid:24267174.

MUSA, M.S., ABDELRASOOL, F.E., ELSHEIKH, E.A., AHMED, L.A., MAHMOUD, A.L.E. and YAGI, S.M., 2011. Ethnobotanical study of medicinal plants in the Blue Nile State, South-eastern Sudan. Journal of Medicinal Plants Research, vol. 5, no. 17, pp. 4287-4297.

NASIR, E. and ALI, S., 1971. Flora of west Pakistan. Karachi: Department of Botany, University of Karachi, pp. 112-115.

NISAR, M. and ALI, Z., 2012. Ethnobotanical wealth of Jandool Valley, Dir Lower, Khyber Pakhtunkhwa (KPK), Pakistan. International Journal of Phytomedicine, vol. 4, no. 3, pp. 351.

NOGUÉS-BRAVO, D., ARAÚJO, M., ROMDAL, T. and RAHBEK, C., 2008. Scale effects and human impact on the elevational species richness gradients. Nature, vol. 453, no. 7192, pp. 216219. http://dx.doi.org/10.1038/nature06812. PMid:18464741.

ONG, H.G. and KIM, Y.-D., 2014. Quantitative ethnobotanical study of the medicinal plants used by the Ati Negrito indigenous group in Guimaras island, Philippines. Journal of Ethnopharmacology, vol. 157, pp. 228-242. http://dx.doi.org/10.1016/j.jep.2014.09.015. PMid:25240586.

PARVAIZ, M., 2014. Ethnobotanical studies on plant resources of Mangowal, District Gujrat, Punjab, Pakistan. Avicenna Journal of Phytomedicine, vol. 4, no. 5, pp. 364-370. PMid:25386399.

QURESHI, S.J. and KHAN, M.A., 2001. Ethnobotanical study of Kahuta from Rawalpindi district Pakistan. Online Journal of Biological Sciences, vol. 1, no. 1, pp. 27-30. http://dx.doi.org/10.3923/ jbs.2001.27.30. 
RAJAKUMAR, N. and SHIVANNA, M., 2009. Ethno-medicinal application of plants in the eastern region of Shimoga district, Karnataka, India. Journal of Ethnopharmacology, vol. 126, no. 1, pp. 64-73. http://dx.doi.org/10.1016/j.jep.2009.08.010. PMid:19686831.

RAZZAQ, A., RASHID, A., ISLAM, M., IQBAL, A. and KHAN, H., 2013. Ethnomedicinal profile and conservation status of plant biodiversity in Alexander the Great Valley, District Shangla, Pakistan. Journal of Medicinal Plants Research, vol. 7, no. 20, pp. 1379-1386.

REHMAN, S., WAZIR, S.M. and FAROOQ A., 2013. Ethnobotanically important plants of Humzoni, NWA, KPK, Pakistan. International Journal of Herbal Medicine, vol. 1, no. 2, pp. 89-101.

SADEGHI, Z., KUHESTANI, K., ABDOLLAHI, V. and MAHMOOD, A., 2014. Ethnopharmacological studies of indigenous medicinal plants of Saravan region, Baluchistan, Iran. Journal of Ethnopharmacology, vol. 153, no. 1, pp. 111-118. http://dx.doi. org/10.1016/j.jep.2014.01.007. PMid:24509152.

SEIFU, T., 2004. Ethnobotanical and ethnopharmaceutical studies on medicinal plants of Chifra district, Afar region. North Eastern Ethiopia. Etiópia: Addis Ababa Univerisity.

SHAH, S.A., SHAH, N.A., ULLAH, S., ALAM, M.M., BADSHAH, H., ULLAH, S. and MUMTAZ, A.S., 2016. Documenting the indigenous knowledge on medicinal flora from communities residing near Swat River (Suvastu) and in high mountainous areas in SwatPakistan. Journal of Ethnopharmacology, vol. 182, pp. 67-79. http://dx.doi.org/10.1016/j.jep.2016.02.008. PMid:26869542.

SHARMA, R., MANHAS, R. and MAGOTRA, R., 2012. Ethnoveterinary remedies of diseases among milk yielding animals in Kathua, Jammu and Kashmir, India. Journal of Ethnopharmacology, vol. 141, no. 1, pp. 265-272. http://dx.doi.org/10.1016/j. jep.2012.02.027. PMid:22366093.

SHER, H. and HUSSAIN, F., 2009. Ethnobotanical evaluation of some plant resources in Northern part of Pakistan. African Journal of Biotechnology, vol. 8, no. 17, pp. 4066-4076.

SHER, Z., KHAN, Z. and HUSSAIN, F., 2011. Ethnobotanical studies of some plants of Chagharzai valley, district Buner, Pakistan. Pakistan Journal of Botany, vol. 43, no. 3, pp. 1445-1452.

SHINWARI, M.I. and KHAN, M.A., 2000. Folk use of medicinal herbs of Margalla hills national park, Islamabad. Journal of Ethnopharmacology, vol. 69, no. 1, pp. 45-56. http://dx.doi. org/10.1016/S0378-8741(99)00135-X. PMid:10661883.

SHINWARI, Z., KHAN, A. and NAKAIKE, T., 2003. Medicinal and other useful plants of District Swat, Pakistan. Peshawar: Al-Aziz Communications, pp. 97-98.

SHINWARI, Z.K. and QAISAR, M., 2011. Efforts on conservation and sustainable use of medicinal plants of Pakistan. Pakistan Journal of Botany, vol. 43, no. 1, pp. 5-10.

SHINWARI, Z.K., 2010. Medicinal plants research in Pakistan. Journal of Medicinal Plants Research, vol. 4, no. 3, pp. 161-176.

SHUAIB, M. and KHAN, I., 2015. Study of Medicinal Plants of Lower Dir, Timergara, Tehsil Balambat, Khyber Paktunkhaw-Pakistan. American-Eurasian Journal of Agricultural \& Environmental Sciences, vol. 15, pp. 2088-2094.

SHUAIB, M., AHMED, S., ALI, K., ILYAS, M., HUSSAIN, F., UROOJ, Z., SHAH, S.S., KUMAR, T., SHAH, M., KHAN, I. and HUSSAIN, F., 2019. Ethnobotanical and ecological assessment of plant resources at District Dir, Tehsil Timergara, Khyber Pakhtunkhwa, Pakistan. Acta Ecologica Sinica, vol. 39, no. 1, pp. 109-115. http://dx.doi. org/10.1016/j.chnaes.2018.04.006.
SHUAIB, M., ALI, K., AHMED, S., HUSSAIN, F., ILYAS, M., HASSAN, N., KHAN, I. and HUSSAIN, F., 2018. Impact of rapid urbanization on the floral diversity and agriculture land of district Dir, Pakistan. Acta Ecologica Sinica, vol. 38, no. 6, pp. 394-400. http://dx.doi. org/10.1016/j.chnaes.2018.04.002.

SHUAIB, M., JANG, N., AYUB, S., UR RAHMAN, S., KHAN, M.T., FAZIL, M. and ALI, Z., 2016. Export of Important Medicinal Plants to Local and International Market from District Dir, Khyber Paktunkhaw-Pakistan. American-Eurasian Journal of Agricultural E' Environmental Sciences, vol. 16, no. 1, pp. 99-103.

SHUAIB, M., KHAN, I., SHARIFULLAH, R.K., HASHMATULLAH, S.M. and NAZ, R., 2014. Ethnobotanical studies of spring flora of Dir Lower, Khyber Pakhtunkhwa, Pakistan. Pakistan Journal of Weed Science Research, vol. 20, no. 1, pp. 37-49.

SIMBO, D.J., 2010. An ethnobotanical survey of medicinal plants in Babungo, Northwest Region, Cameroon. Journal of Ethnobiology and Ethnomedicine, vol. 6, no. 1, pp. 8. http:// dx.doi.org/10.1186/1746-4269-6-8. PMid:20156356.

SRITHI, K., BALSLEV, H., WANGPAKAPATTANAWONG, P., SRISANGA, P. and TRISONTHI, C., 2009. Medicinal plant knowledge and its erosion among the Mien (Yao) in northern Thailand. Journal of Ethnopharmacology, vol. 123, no. 2, pp. 335-342. http://dx.doi. org/10.1016/j.jep.2009.02.035. PMid:19429381.

STEWART, R.R., 1967. Check list of the plants of Swat State, Northwest Pakistan. [S.l.: s.n.].

THE PLANT LIST, 2013 [viewed 1 January 2021]. The Plant List. Version 1.1. Available from: http://www.theplantlist.org/.

TOLOSSA, K., DEBELA, E., ATHANASIADOU, S., TOLERA, A., GANGA, G. and HOUDIJK, J.G., 2013. Ethno-medicinal study of plants used for treatment of human and livestock ailments by traditional healers in South Omo, Southern Ethiopia. Journal of Ethnobiology and Ethnomedicine, vol. 9, no. 1, pp. 32. http:// dx.doi.org/10.1186/1746-4269-9-32. PMid:23680260.

TROPICS [online], 2021 [viewed 18 August 2021]. Available from: http://www.tropics.org/project/Pakistan.

ULLAH, A., RASHID, A. and AMAN, S., 2006. Trees and Livelihood of Gabral Valley, Swat, Kohistan, Pakistan. Pak. J. For, vol. 56, no. 1, pp. 46-52.

UMAIR, M., ALTAF, M. and ABBASI, A.M., 2017. An ethnobotanical survey of indigenous medicinal plants in Hafizabad district, Punjab-Pakistan. PLoS One, vol. 12, no. 6, pp. e0177912. http:// dx.doi.org/10.1371/journal.pone.0177912. PMid:28574986.

YINEGER, H., KELBESSA, E., BEKELE, T. and LULEKAL, E., 2007. Ethnoveterinary medicinal plants at bale mountains national park, Ethiopia. Journal of Ethnopharmacology, vol. 112, no. 1, pp. 55-70. http://dx.doi.org/10.1016/j.jep.2007.02.001. PMid:17368989.

ZAHOOR, M., WAZIR, S., MOHAMMAD, A. and MOHAMMAD, S., 2009. Ethnobotany of some plants from Darra'e Pezo, District Lakki Marwat, Pakistan. Pakistan Journal of Plant Sciences, vol. 15, no. 1, pp. 75-80.

ZAHOOR, M., YOUSAF, Z., AQSA, T., HAROON, M., SALEH, N., AFTAB, A., JAVED, S., QADEER, M. and RAMAZAN, H., 2017. An ethnopharmacological evaluation of Navapind and Shahpur Virkanin district Sheikupura, Pakistan for their herbal medicines. Journal of Ethnobiology and Ethnomedicine, vol. 13, no. 1, pp. 27. http://dx.doi.org/10.1186/s13002-017-0151-1.

ZAMAN, S. and HAZRAT, A., 2013. Ethnobotanical survey of medicinal plants from tehsil dargai, district Malakand, Pakistan. FUUAST Journal of Biology, vol. 3, no. 1, pp. 109. 